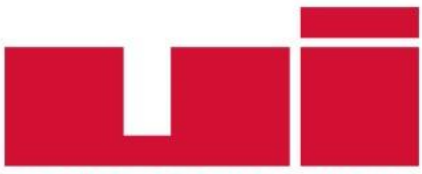

ULLUSLARARASliLiŞKiLER
Akademik Dergi

Yayın ilkeleri, izinler ve abonelik hakkında ayrıntılı bilgi:

E-mail: bilgi@uidergisi.com.tr

Web: www.uidergisi.com.tr

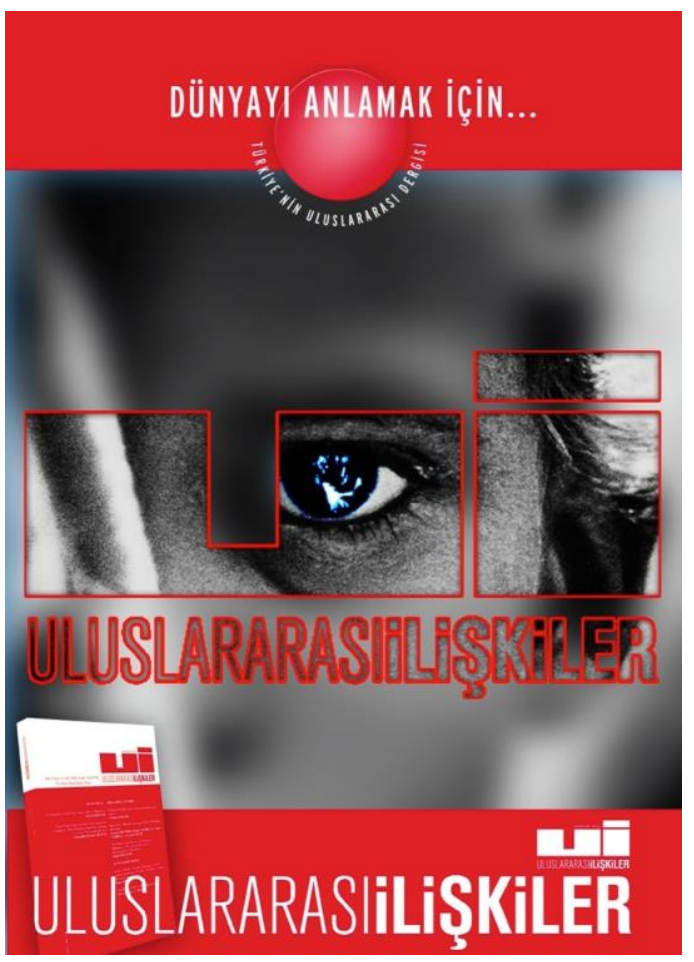

\section{Gramsci, Cox ve Hegemonya: Yerelden Küresele, Iktidarın Sosyolojisi $\ddot{U}$ zerine} Mehmet Akif OKUR*

* Doç. Dr., Gazi Üniversitesi, Uluslararası İlişkiler Bölümü

Bu makaleye atıf icin: Okur, Mehmet Akif, "Gramsci, Cox ve Hegemonya: Yerelden Küresele, İktidarın Sosyolojisi Üzerine”, Uluslararası Illişkiler, Cilt 12, Sayı 46, s. 131-151.

Bu makalenin tüm hakları Uluslararası İlişkiler Konseyi Derneği’ne aittir. Önceden yazılı izin alınmadan hiç bir iletişim, kopyalama ya da yayın sistemi kullanılarak yeniden yayımlanamaz, çoğaltılamaz, dağıtılamaz, satılamaz veya herhangi bir şekilde kamunun ücretli/ücretsiz kullanımına sunulamaz. Akademik ve haber amaçlı kısa alıntılar bu kuralın dışındadır.

Aksi belirtilmediği sürece Uluslararası İlişkiler'de yayınlanan yazılarda belirtilen fikirler yalnızca yazarına/yazarlarına aittir. UİK Derneğini, editörleri ve diğer yazarları bağlamaz.

Uluslararası İlişkiler Konseyi Derneği | Uluslararası İlişkiler Dergisi

Web: www.uidergisi.com.tr|E- Posta: bilgi@uidergisi.com.tr 


\title{
Gramsci, Cox ve Hegemonya: Yerelden Küresele, İktidarın Sosyolojisi Üzerine
}

\section{Mehmet AKİF OKUR}

Doç. Dr., Uluslararası İlişkiler Bölümü, Gazi Üniversitesi, Ankara. E-posta: mehmetakifo@yahoo.com

\section{ÖZET}

Uluslararası sistemi derinden etkileyen kriz ve dönüşümler, teorik perspektiflerin yeni konjonktüre ait dinamikler karşısında kendilerini yenilemeleri için bir çağrı niteliği de taşımaktadır. Bu yönde atılabilecek ilk adımlardan biri, kuramların temel önermelerinin zihinsel evrim süreçleri dikkate alınarak gözden geçirilmeleridir. Bu makalede, RobertW.Cox'un Eleştirel Kuramı'ndamerkezibiryere sahip “hegemonya” kavramı ve etrafinda kurgulananiktidar mantığ1, entelektüel köklerinin dayandığı Antonio Gramsci'nin çalışmalarıyla mukayeseli olarak incelenmektedir. Makalenin ilk kısmında Gramsci ve Cox'un pozitivizm karşısındaki tavırları, tarihselci epistemolojileri, tarihsel yapılar ve insan eyleminin sınırları arasında kurdukları denge ile kültüre, öznelerarası anlamlar ve kolektif imajlar formundaki fikirlere kuramlarında açtıkları alan ele alınmaktadır. Takip eden kısımlarda ise, ikilinin yerel ve küresel düzeylerdeki hegemonya analizleri mercek altına yatırilmaktadır.

Anahtar Kelimeler: Hegemonya, Robert W. Cox, Antonio Gramsci, Eleştirel Kuram.

\section{Gramsci, Cox and Hegemony: From Local to Global on the Sociology of Power}

\begin{abstract}
Serious crises and transformations, deeply affecting the international system, create a conducive environment in which theoretical perspectives feel an urge to review themselves against the dynamics of the new conjuncture. One of the first steps that can be taken to satisfy this urge is to revievaluate the main tenents of the theories by taking their evolution processes into consideration. fte aim of this study is to contribute to the intellectual efforts in this direction by focusing on one of the core concepts of Neo-Gramscian studies: "hegemony", that has a central place in the Critical fteory of Robert Cox. ftroughout the article, Coxian "hegemony" and the ruling logic behind it will be examined in comparison with the works of Antonio Gramsci, who laid the intellectual grounds of the concept. fte first section is devoted to Gramsci's and Cox's positions vis-a-vis positivism, their historicist epistemology, the balance that they have created between historical structures and the limits of human action as well as the place they opened for culture, intersubjective meanings and collective images in their theories. In the following sections, both authors' understandings of hegemony within the local and global contexts will also be examined.
\end{abstract}

Keywords: Hegemony, Robert W. Cox, Antonio Gramsci, Critical fteory. 



\section{Giriş}

1980’lerde hegemonya kavramı etrafında kuram inşa eden Robert W. Cox'un yeni-Gramşiyan perspektifini etkileyip besleyen metodolojisi, özellikle belirsizlik dönemlerinin anlamlandırılması ve gelecek ihtimalleri hakkında düşünülmesini kolaylaştıran önemli analitik imkanlara sahiptir. Bu imkanların kullanılması ve yeni-Gramşiyan okulu var eden dinamizm, kuramın ihtiyaç duyduğu yenilenmeyi sağlayarak canlandırabilir. Çünkü, teorik yaklaşımlar, soyut önermelerinin penceresinden analiz edilen tarihsel dönemlere ait ilişki biçimleri ve tarihsel yapılarla özdeşleştirilme riskiyle yüz yüzedirler. Yeni bir konjonktüre geçildiğinde, kuramların temel varsayımlarının pratik sorular karşısında yorumlanmasına dayanan birçok metin, inceledikleri konular ve problem alanlarıla beraber tarihselleşmektedir. Bu yüzden dış dünyada büyük dönüşümlerin yaşandığı süreçlerde, kullanılagelen teorik çerçevelerin dayandığı entelektüel köklerin hatırlanması ve üzerlerine inşa edildikleri kavram dünyasının temellerine yapılan referanslarla güncellenmesi, söz konusu kuramların yeni sorunlara uyarlanarak varlıklarını koruyabilmeleribakımındanönem taşımaktadır.

Bu kapsamda, dünya ekonomisi ve politikasının çok boyutlu gelişmelere şahit olduğu günümüzde, küreselleşme çağına ait iktidar ilişkilerini analiz ederek serpilen yeni-Gramşiyan perspektif de, tıpkı diğer yaklaşımlar gibi, "küreselleşme-sonrası” tartışmalarıyla yüzleşmek durumundadır. ${ }^{1} \mathrm{Yu}$ karıda işaret edilen problemin aşılabilmesi için ise, bu yüzleşmeye girişmeden önce, geriye dönülerek kuramın mirasına doğru bir yolculuğa çıkılması gereklidir. Böylece, Antonio Gramsci’nin yazılarına uzanacak bir zihinsel seyahat aracılığıyla yeni-Gramşiyan okulun başvurduğu temel kavram setinin orijinal bağlamları ve evrim güzergahlarının merkeze alınarak gözden geçirilmesi, yeni dinamiklerin yorumlanması çabalarını destekleyici bir rol oynayacaktır.

Bu doğrultudaki faaliyetlere katkıda bulunmak amacındaki bu çalışmada, kuramın öncü ismi Robert W. Cox ile Antonio Gramsci'nin çalışmaları arasındaki ilişkiye odaklanarak, kuramın doğuş döneminin entelektüel kökleri mercek altına yatırılacaktır. Önce her iki ismin de benimsedikleri tarihselcive anti-pozitivist epistemoloji ile kullandıkları temelkavramlararasındaki bağlantılarelealınacak, ardından da Cox'un Uluslararası İlişkiler/uluslararası politik ekonomi alanına uyarladığı hegemonya analizi, kavramı devşirdiği Gramsci'nin yazılarıyla mukayeseliolarakincelenecektir.

\section{Gramsci ve Cox'ta Tarihselcilik: Fikirler ve Maddi Şartlar Arasında Denge Arayışı}

Sosyal teori içinde çeşitli yorumlanış ve uygulanış biçimleri bulunan tarihselciliğin, ${ }^{2}$ yeni-Gramşiyan okul üzerinden Uluslararası İlişkilerveuluslararası politik ekonomi çalışmalarına taşındı̆̆ıüzergâhta, Gramsci'nin metinlerinin felsefi realizmin eleştirel bir versiyonu açısından okunması sıklıkla karşımıza çıkar. ${ }^{3}$ Aşağıda görüleceğiüzere, Vico, Braudel veSorel’in de katkılarıyla bu bileşim; yapı ve aktörle-

1 Küreselleşme-sonrası (Post-Globalization) tartışmaları için bkz. Mehmet AkifOkur, "Millet-İmparatorluklar Çağının Eşiğinde: GenişleyenDünyada Küresel Kapitalizmin YeniMimarisineDoğru,’Türkiye Günlüğ̈̈,No95,2008, s. 82-118.

2 Tarihselcilik (Historicism) kavramının sosyal bilimlerdeki muhtelif kullanımlarına ilişkin genel değerlendirmeler için bkz.G.Duncan Mitchell (der.),ANew Dictionaryof the Social Sciences, NewJersey, Transaction Publishers, 2007, s. 9597; Nicholas Bunnin ve Jiyuan Yu, The Blackwell Dictionary of Western Philosophy, Oxford, Blackwell, 2004, s. 307-308; William Outhwaite, The Blackwell Dictionary of Modern Social Thought, Oxford, Blackwell, 2003, s. 271-272.

3 Felsefi realizm, en temelde, gerçekliğin bizim onun hakkındaki tasavvurlarımızdan bağımsız olarak varolduğunu kabul eden bakıș açısıdır. Bkz. Alexander Avni ve Mira Sucharov, "Philosophical Realism", Routledge Encyclopedia of International Political Economy, R. J. Barry Jones (der.), Londra, Routledge, 2001, s. 1212-1213. Esteve Morera da, bazı metinlerinden hareketle Gramsci’nin düşünceleriyle uyumlu olduğunu düşündüğü felsefi realizmi iki temel 
rin nitelikleri, birbirleriyle ilişkileri, devamlılık ve kırılganlıkları, eylem çerçeveleri gibi temel tartışma konuları için maddi şartlar ve fikirlerin özel parametreler tarafından belirlenen etkileşimini esas almak suretiyle, indirgemecilikten uzaklaşan ve değişime odaklı bir analiz çerçevesi sunmaya çalışır.

Bu çerçeveyi daha yakından kavramaya, yeni-Gramşiyan eleştirel kuramın beslendiği düşünce kaynağının pozitivizme yönelttiği tenkitlerle başlamak, kuramın hangi yetersizlik ve ihtiyaçlar karş1sında ne türden bir cevap verme iddiasıyla ortaya çıktığını göstererek, daha sonra değerlendirilecek temelönermelerin anlaşılmasını kolaylaştırması bakımından yararlıolacaktır.

Gramsci,Bukharin'in metodolojisini değerlendirdiğimakalesindekaba materyalizmin indirgemeci mantığını açıkça reddetmiştir. ${ }^{4}$ Konuyla ilgili önemli çalışmasında, Merrington da, Gramsci'nin doğa bilimlerindeki kesinlikle geleceği öngörmeye çalışan bir sosyal bilim anlayışını kabullenmediğinedikkatçekmektedir. ${ }^{5}$

Gramsci'nin düşüncelerini 20. yüzyllın son çeyreğinde Uluslararası İlişkiler disiplini ile buluşturan Robert W. Cox da, teknik rasyonalite aracıllŏı̆la objektifliğe eriştiği iddiasında bulunan pozitivizmin datayla/verilenlerle, tarihselciliğin ise olgularla/yapılanlarla ilgilendiğine ve hedef sahibi bir yaratıcı varsaydığına işaret etmektedir. Bu açıdan pozitivistin gözünde olgular dataya indirgenmektedir. Bunun ise iki türlü bozucu etkisi olmaktadır. Öncelikle, aktör ya da eylemde bir araya gelen düşünceler, duygular ve baskılar eylemden uzaklaştırılmakta, geride sadece etki ve sonuç kalmaktadır. İkinci olarak ise, olayın kendisine anlam veren karmaşık bağlamı, bütün bağlantılanı, ilişkileri ve çelişkilerinden soyutlanmaktadır. ${ }^{6}$

Sosyal fenomenleri içkin sebeplerle açıklamaya çalışan tarihselciperspektif, tarihselvarlığıiçinde insanı eylemin merkezine yerleştirirken, değişimi üzerinden açıklayacağı ana güzergâha da işaret etmektedir. Bu insan, soyut, sabit ve değişmez bir doğa tarafından belirlenmiş değildir. İnsan tabiat1, tarihsel olarak varlık kazanan sosyal ilişkilerin toplamı şeklinde tanımlanmakta, dolayısıyla da değişken niteliği vurgulanmaktadır. ${ }^{7}$ Cox bu tartışmay1, Vico ve Descartes’a kadar geri götürmektedir. Aydınlanma düşüncesinin temsilcisi Descartes'a ait, tekil tabiatlı insanın zihninde kavrayacağı tekil ve rasyonel hakikat iddiasının karşısına, Vico’nun insan doğalarının çeşitlilik arz ettiği ve değişik tarihler tarafından şekillendirilmiş farklı gerçekliklerin varlığını kabul eden perspektifini yerleştirmektedir. ${ }^{8}$

Gerçekliğin kavranışındaise, felsefi realizmin diyalektik birversiyonuna başvurulmaktadır. Bağımsız olarak mevcutbir dış dünya varsayılmakta, ardından da bu gerçekliğin kavranmasına imkan vereceközelbirepistemolojidevreyesokulmaktadır. ${ }^{9}$ Felsefigerçekliğin Gramşiyanyorumu,entelektüel

Özellik etrafında tanımlamaktadır: Gerçekliğin bağımsız olarak varoluşunun kabulü ve gerçekliği yansıtan bir bilgi kavramlaştırması. Bkz. Esteve Morera, Gramsci's Historicism: A Realist Interpretation, Londra, Routledge, 1990 , s. 41.

4 Antonio Gramsci, Selections From the Prison Notebooks of Antonio Gramsci, Quentin Hoare (der.), çev. G. Nowell Smith, New York, International Publishers,1978, s. 1424-1425.

5 John Merrington, “fteory and Practice in Gramsci’s Marxism”, New Left Review (der.), Western Marxism, A Critical Reader,Londra, Verso, 1978, s. 143.

6 Robert W. Cox ve Michael G. Schechter, The Political Economy of a Plural World: Critical Reflections on Power, Morals and Civilization, Londra, Routledge, 2002, s. 59. Cox, Collingwood'a atıfla, olayların hem iç hem de dış yüzlerinin bulunduğunu söylemektedir. Dış yüz, olayın dışarıdaki gözlemci tarafindan veri olarak kaydedilen kısmıdır. Tarihçinin anlamaya çalıştığı iç yüz ise, yapılmış bir şey olarak olay1 "gerçek” kılan arkadaki düşüncedir. Bkz. Robert W. Cox, "fte International in Evolution", Millennium: Journal of International Studies, Cilt 35, No 3, 2007, s 514.

7 Maurice A. Finocchiaro, Gramsci and the History of Dialectical Thought, New York, Cambridge University Press,1988, s.135.

8 CoxveSchechter,The PoliticalEconomyofaPlural World, s. 56.

9 Morera, Gramsci's Historicism, s. 41. 
faaliyeti, dışarıdaki sosyal gerçekliği açıklamak için yaratıcı, açık uçlu ve sürekli bir uğraş şeklinde tarif etmektedir. Bu faaliyet, tarihi sürecin bir parçasıdır ve onun dışında durmamaktadır. ${ }^{10}$

Cox’un epistemolojisinde de dış dünya ile zihinsel süreçler arasındaki karşılıklı etkileşim, teorik faaliyetin başlangıç noktasıdır. Cox bu çift yönlü süreci, tarihin objektif hareketleri ve sübjektif idrakler arasındaki ilişki üzerinden açıklamaktadır. Birbirleriyle bağlantılı güç kombinasyonlarını ortaya ç1karan, tarihin objektif hareketidir. Sübjektifidrakler de tarihin hareketini anlamak ve ona uygun davranmak için bu güçler üzerinde düşünmektedirler. Yaşananlar analizcinin şuur ve idrakini etkilerken, analizcinin zihni de tarihin hareketini anlama tarzını biçimlendirmektedir. ${ }^{11}$

Morera'nın yorumladığı şekliyle, Gramşiyan tarihselciliğin penceresinden bakıldığında, en istikrarlı yapılar bile değişimin etki alanı dışında kalamadıkları için, sosyal dünya üzerine düşünmek geçici bir süreçle ilgilenmek demektir. ${ }^{12}$ Fakat, değişime sebep olabilecek sosyal etkileşim, "mümkün olanın sınırları" şeklinde ifade edilebilecek çerçevelerde meydana gelmektedir. Örneğin, Gramsci'ye göre tarihsel bir dönemin ihtiyaçlarına tekabül etmeyen bir ideoloji, daha sonra özel şartlar sayesinde popülerlik kazanabilse de, tarihsel rekabette er ya da geç saf dışı kalacaktır. Mümkün olanın sınırları sabit ve değişmez olmamakla birlikte, verili sosyal yapının içinde mevcuttur. Bu yapılar aktörler tarafindan ancak kolektif faaliyet yoluyla değiştirilirler. ${ }^{13}$

Gramsci'nin tarihsel değişmenin dışında kalmamakla birlikte, hem değişim imkânları hem de değişimin doğrultusu üzerinde belirleyici olan yapısal sınırlar düşüncesi, Cox’un tarihsel yapıları arac1lığıyla uluslararası politik ekonomi alanına taşınmıştır. Zihni inşalar olan bu yapılar, belirli tarihsel dönemlerdeki kolektif insan faaliyetinin kümülatif sonuçlarını özetlemektedirler. ${ }^{14}$ Uzun vadede şekil kazanan Cox'un tarihsel yapıları içinde maddi kabiliyet, fikir ve kurumların oluşturdukları ve birbirleriyle etkileşim halindeki üç güç kategorisi bulunur. ${ }^{15} \mathrm{Bu}$ kapsamda tarihsel yapılar, üretimin örgütlenmesi, devlet biçimleri ve dünya düzenleri ile bunlar arasındaki ilişkinin incelenmesinde Weberci ideal tiplere benzer bir işlev görürler. Bu yapılar ayrıca araştırma yapılan alana ait karmaşık gerçekliği tutarlı bir şekilde resmederken, alternatif tarihsel yapıların oluşum ihtimallerinin değerlendirilmesine vekarşılaştırmalar yapılmasına daimkân vermektedirler. ${ }^{16}$

Genel Althusserci yaklaşımı, ${ }^{17}$ failin rolünü inkâr eden katı bir tarihsel ve yapısal determinizmi birleştirdiği için reddeden Cox'un tarihsel yapıları eylemi belirlememekte, ${ }^{18}$ fakat eylemin şekil kazanmasında etkili olan beklenti, alışkanlık ve baskıların sınırlarını çizerek eylemin gerçekleştiği bağlama işaret etmektedirler. ${ }^{19}$ Cox devletleri, konfederasyonları, imparatorlukları, üretimin ve kültürel cemaatlerin organizasyonu ile sivil toplum hareketlerine dair muhtelif gelişmeleri, sosyal örgütlen-

10 Ibid., s. 38-53.

11 CoxveSchechter,The PoliticalEconomyofaPlural World, s.26.

12 Morera, Gramsci's Historicism, s.36,74-93.

13 Gramsci, Selections From the Prison Notebooks, s. 341. Morera, Gramsci's Historicism, s. 37-38, 94-114.

14 Coxve Schechter,The PoliticalEconomy ofa Plural World, s. 78.

15 TimothyJ.Sinclair, "Beyond International Relations fteory", RobertW.CoxveTimothyJ.Sinclair,Approachesto World Order, Cambridge, Cambridge University Press, 1996, s. 8-11.

16 RobertW.Cox, “SocialForces,States and WorldOrders:BeyondInternationalRelationsfteory”, Millennium: Journalof International Studies, Cilt 10, No 2, 1981, Robert W. Cox ve Timothy J. Sinclair, Approaches to World Order, Cambridge, Cambridge University Press, 1996, s. 100.

17 Louis Althusser'in anti-humanist Marksizm yorumu ve yapisalc1lık anlayışı için bkz. Louis Althusser, For Marx, çev. Ben Brewster,Londra, Verso, 2005.

18 John M. Hobson, The State and International Relations, Cambridge, Cambridge University Press, 2000, s.129.

19 Cox, "Social Forces, States and World Orders", s. 97-98. 
menin farklı şekillerini ifade eden tarihsel yapılara örnek göstermektedir. Bunlar, irsîlik, ebedilik ya da evrensellik gibi özellikler taşımayan, insanlar tarafından tarih boyunca yaratılıp değiştirilen tarihsel yapılardır; hepsi geçicidir ve toplumların kendilerini değişik şekillerde örgütlemelerinin ürünüdür. ${ }^{20}$

Yapıların yalnızca maddi güç unsurlarıyla temellendirilmeyerek, hem oluşum hem de değiştirilmelerinde fikirlere ve insan faaliyetine yer açılışı, arınma (catharsis) aracılığı ile objektiften sübjektife ve zorunluluktan özgürlüğe geçişi mümkün gören Gramşiyan yapı anlayışıyla uyumludur. ${ }^{21}$ Tarihteki değişimlerin, büyük ölçüde kolektif insani çabaların sonucu olduğunu düşünen Gramsci, analizlerinde yapıya insanı ezen, kendi içinde eriten ve pasifleştiren harici bir kuvvet olarak bakmamakta; yapıyı bir özgürlük aracına, yeni bir ahlaki-siyasi forma ve yeni inisiyatiflerin kaynağına dönüştürme imkânlarına odaklanmaktadır. ${ }^{22}$

Bubakış, Gramsci’nin kuvvetilişkilerianalizinde dekendisinigöstermektedir. Bunagöre sosyal kuvvetlerin tarihin seyrine etki edecekleri sürecin ilk ânı (moment), yapıyla bağlantılı ve objektiftir; maddi üretim güçlerinin ve sosyal sınıfların doğuşu ile aralarındaki münasebetleri yansıtır. ${ }^{23}$ Siyasi güçlerin ilişkileriyle ilgili ikinci âna ait ekonomik-kolektif nitelikteki ilk aşamanın belirgin özelliği, grubun varlığının farkında olması, ancak dayanışmanın bulunmamasıdır. İkinci aşamada, ekonomik ya da diğer kolektif çıkarlarla sınırlı bir dayanışma zemini oluşmaktadır. Yapının üst yapının içine geçtiği üçüncü ve en siyasi ânda ise entelektüel ve ahlâkî birlik zuhur etmekte, Gramsci'nin modern Prensi, yani siyasi partiler doğmaktadır. ${ }^{24}$

Cox’un, ulusaşırı ilişkiler matriksinin içine yerleştirdiği sosyal kuvvetler de, yukarıda işaret edilen Gramşiyan köklerinin renklerini taşımaktadırlar. Sırasıyla üretim süreçleri, sınıflar arası ilişkiler ve siyasi güç arasındaki etkileşim, tekil siyasi toplumlanı aşan bir ulusaşırı düzlemde dünya politik ekonomisinin çehresini belirlemektedir. ${ }^{25}$

Cox, tarihsel yapıları ve sosyal kuvvetleri maddi yönlerini aşan bir çerçevede tanımlarken, sosyal değişmeyi bütünüyle ekonomik terimlerle açıklayan görüşler karşısında kültürel olana açtığı yerle, tarihsel değişmede fikirlerin rolü hususunda en önemli teorisyenlerden biri kabul edilen Gramsci'nin geleneğini izlemeye devam etmektedir. ${ }^{26}$ Gramsci'nin tarihsel materyalizminde fikirler ve maddî şartlar daima birbirleriyle bağlantılıdırlar, karşılıklı olarak birbirlerini etkilemektedirler ve birbirlerine indirgenemezler. Fikirler maddî şartlarla ilişkileri dikkate alınarak anlaşılmak zorundadır. ${ }^{27} \mathrm{Bu}$ yüzden,

20 Cox, "fte International in Evolution", s. 516.

21 Norberto Bobbio, “Gramsciand theConception ofCivil Society”, ChantalMouffe (der.), GramsciandMarxist Theory, Londra, Routledge, 1979, s.33-34. Robert S. Dombroski, Antonio Gramsci, Boston, Twayne Publishers, 1989, s.120. WalterL.Adamson, "Beyond 'Reform or Revolution': Notes on Political Education in Gramsci, Habermas and Arendt", James Martin (der.),Antonio Gramsci, Critical Assessments of Leading Political Philosophers, Londra, Routledge, 2002, s. 297-298; Morera, Gramsci’s Historicism, s.58.

22 Stephen Gill, “Epistemology, Ontology and the 'Italian School”, Stephen Gill (der.), Gramsci, Historical Materialism and International Relations, Cambridge, Cambridge University Press, 1993, s. 22; Gramsci, Selections From the Prison Notebooks, s. 366-367.

23 Ibid.,s.180.

24 Ibid.,s.181.

25 Cox, "SocialForces, States and World Orders", s.105-111.

26 James H. Mittelman, "Rethinking Innovation in International Studies: Global Transformation at the Turn of the Millenium”, Stephen Gill ve James H. Mittelman (der.), Innovation and Transformation in International Studies, Cambridge, Cambridge University Press, 1997, s. 253.

27 Robert W. Cox, “Gramsci, Hegemony and International Relations: An Essay in Method”, Stephen Gill (der.), Gramsci, Historical Materialism and International Relations, Cambridge, Cambridge University Press, 1993, s.56. 
örneğin siyasal ve kültürel pratikler, ekonomik kuvvetler ya da çıkarlara indirgenemezken, ${ }^{28}$ sanat, ahlâk ve felsefe siyasete hizmet edebilir. Böylece bütün hayat, siyasetin sınırları içine girer ${ }^{29}$ Böylece, çatışma şartlarını belirlemek için verilen mücadelede stratejik bir "savaş alanı" kabul ettiği kültürün önemini vurgulayan Gramsci’nin yaklaşımı, sosyal bilimlerde eleştirel gelenek içinden kültürle ilgilenen hemen herkesin ilgilendiği bir alana dönüşür. ${ }^{30}$

Anti-ekonomist ${ }^{31}$ sifatiyla nitelenebilecek derecede metodolojik indirgemeciliği eleştiren Gramsci, ${ }^{32}$ ideolojilerin maddi bir kuvvetle aynı enerjiye sahip olduklarını söylemektedir. ${ }^{33}$ Kolektif eylem hakkındaki temel soruları anlamak için önerdiği ekonomi merkezci olmayan perspektif, ${ }^{34}$ sadece kısa vadeli bireysel çıkarların değil, uzun vadeli kolektif arzuların da insanları eylem için motive ettiklerini kabul etmektedir. ${ }^{35} \mathrm{Bu}$ varsayımı temellendirirken, düşünmenin bireyi nasıl harekete geçirdiği, bir kimsenin nasıl ve niçin fikirlerle hareket edebildiği ve fikirlerin nasıl pratik/ fillî güçler haline geldiği sorularına çalışmalarında ağırlıklı yer vermektedir. ${ }^{36}$

Tarihsel materyalizmi, Gramsci’nin eleştirileri ışığında Sorel ve Weber'e yaptığı atıflar ile fikirler ve maddi şartlar arasındaki ilişkinin araştırılması şeklinde tarif eden Cox, fikirleri özneler arası anlamlar ve kolektif imajlar olmak üzere ikiye ayırmaktadır. ${ }^{37}$ Özneler arası anlamlar ile, dünyanın doğasına dair bir insan grubu arasında mevcut bulunan hâkim algıyı ya da ortaklaşa paylaşılan "hakikat" anlayışını kast eden Cox'un kullandığı şekliyle özneler arasılık, toplumların varoluş şartları karşısında verdikleri kümülatif ortak cevaplar tarafindan üretilen bilgi şeklinde de anlaşılabilir. ${ }^{38}$ Cox, tarihsel yapıların derinliklerindeki ana özneler arası anlam kategorilerine örnek olarak dünyanın anlaşılmasını sağlayan, toplumlara ve çağa ait sağduyu ile iletişimi mümkün kılan dili göstermektedir. ${ }^{39}$ Yeni-Gramşiyan yaklaşım, tarihin bir ürünü olan özneler arası anlamlar formundaki bu fikirleri, politik ekonominin bizzatparçası kabul etmektedir. ${ }^{40}$

Genellikle fazla sorgulanmayan özneler arası anlamların aksine kolektif imajlar ise, yoğun tartışmaların odağında yer almaktadır. Örneğin geniş kitleler, birerözneler arası anlamı ifade eden devlet ve devlet sistemini ontolojik hakikatler gibi görmektedirler. Fakat devletin ve devletlerarası sistemin fiilî örgütlenme biçimi üzerine yürütülen tartışmalar, mevcut devletler ve devletlerarası yapı içindeki güçilişkilerinin meşruiyetlerinin farklı ideolojik konumlardan hedef alındıkları bir savaş alanını andırmaktadır. ${ }^{41}$

28 Gramsci, Selections From the Prison Notebooks, s. 407.

29 Finocchiaro, Gramsci and the History of Dialectical Thought, s.134.

30 Jesús Martín-Barbero, Communication, Culture andHegemony, Fromthe Media to Mediations, Elizabeth Fox ve Robert A. White (çev.), Londra, Sage Publications, 1993, s.73-74.

31 Michele Barrett, Marx'tan Foucault'a İdeoloji, Ahmet Fehmi (çev.), İstanbul, Mavi Ada Yayıncılık, 2000, s. 66.

32 Gill, "Epistemology, Ontology and the 'ItalianSchool",s.24.

33 Gramsci, Selections From the Prison Notebooks, s.377.

34 Enrico Augelli ve Craig N. Murphy: "Consciousness, Myth and Collective Action: Gramsci, Sorel and the Ethical State”, Stephen Gillve James H. Mittelman (der.), Innovation and Transformation in International Studies, Cambridge, Cambridge University Press, 1997, s. 25.

35 Ibid.,s.37.

36 Giuseppe Fiori, Antonio Gramsci: Life of a Revolutionary, Tom Nairn (çev.), Verso Books, 1996, s.93.

37 CoxveSchechter, The PoliticalEconomyofaPlural World, s.28.

38 Ibid., s.89.

39 Cox, "fte International in Evolution", s. 516.

40 Andreas Bieler and Adam David Morton, "ACritical fteory Route to Hegemony, World Order and Historical Change: Neo-Gramscian Perspectives in International Relations”, Capital \& Class, No 82, 2004, s. 100.

41 Cox, "Social Forces, States and World Orders", s. 99. 


\section{Hegemonya: Gramsci ve Íktidarın Sosyolojisi}

Cox’un İkinci Dünya Savaşı sonrasında şekillenen ABD liderliğindeki dünya düzeninin açıklanması problematiği çerçevesinde Uluslararası İlişkilere uyarladığı hegemonya teorisinin köklerinde, Gramsci'nin İtalyan toplumu üzerine yaptığı iktidarın doğasına ilişkin analizler yatmaktadır. ${ }^{42}$ Gramsci'nin temel problematiği, bir toplumda sınıfların ya da sosyal grupların hâkimiyeti nasıl ele geçirdikleri ve sürdürdükleri sorusudur. İktidarı anlama üzerine yoğunlaşan sosyolojik düşüncenin hedefi, muhalefet imkânlarının ve istikrarlı bir karşı iktidara giden yolun keşfidir. Zira Gramsci'ye göre, siyasi mücadele içinde bulunduğu burjuvazinin başarılı bir şekilde devrilebilmesi, ancak bu sınıfın gücü elinde nasıl tuttuğunun tatmin edici analizine bağlıdır. ${ }^{43}$

Gramsci'nin iktidar analizinin çatı kavramını oluşturan hegemonya, fizikî güç ya da "zorlama” ile; entelektüel, moral ve kültürel ikna ya da "rıza” yı birleştiren sosyal ve politik bir kontrol tarzıdır. Hegemonik bir düzenin karakteristiği olarak sınıflar, devlet ve sivil toplum arasındaki ilişkilere "zor"dan ziyade "rıza"nın hâkim oluşu gösterilmektedir."

Bu kapsamda, bir ideal tip olarak Gramşiyan hegemonyanın hayata geçmesi için ikincil sınıfların, hakim sınıf ya da gruplara ait moral ve kültürel değerleri, pratik ilişki kodlarını ve dünya görüşlerini, yani hakimiyet sisteminin bizatihî sosyal mantığını içselleştirmeleri icap etmektedir. Bu mantık, sosyal bütünleşmede yapıştırıcı bir kuvvet ya da Gramsci’nin deyimiyle çimento işlevi gören ideolojinin içinde mündemiçtir. ${ }^{45}$ “İkincil ve hakim olunan sınıfların önemli bölümlerinin rızasını kazanmak, çok farklı pozisyon ve çıkarları temsil etmek” hegemonik ideolojinin özellikleri arasındadır. ${ }^{46}$ İdeoloji aracılı̆̆ıyla, ikincil sınıfların görünürdeki çıkarları, siyasi liderliği yürüten hâkim sınıfınkilerle irtibatlandırılmaktadır. ${ }^{47}$ Fakat ideolojiden daha fazla şey ifade eden ve bu yönüyle Marx’ın “yanlış idrak”'ine indirgenemeyen hegemonya, ${ }^{48}$ farklı sınıf ve grupları ikincil unsurların hâkim güç tarafindan empoze edilen sosyal hayat doğrultusunda rızalarını kendiliğinden gösterdikleri gönüllü kabule dayalı bir hâkimiyet ortamında birbirine bağlamaktadır. ${ }^{49}$ Böylece geniş bir siyasal oydaşma, hegemonik sınıfin hedeflerini desteklerken, hegemon da müttefiklerinin çıkarlarına dikkat etmekte, onları, üretim biçimi içindeki pozisyonlarından kaynaklanan eğilim ve talepleriyle diğer ideallerinden doğan arzularını tatmin etmek suretiyle kontrol altında tutmaktadır. ${ }^{50}$

Hegemonik iktidarı farklı k1lan riza unsuru olsa da, bu durum, zorun tamamen ortadan kalktığı anlamına gelmemektedir. Tutarlı bir sosyal düzenin otoriter ya da demokratik siyasal üst yapıla-

42 Stephen Gill, "Gramsciand GlobalPolitics:Towardsa Post-HegemonicResearch Agenda”,Stephen Gill(der.), Gramsci, Historical Materialism and International Relations, Cambridge, Cambridge University Press, 1993, s. 3.

43 Gramsci, Selections From the Prison Notebooks, s. 443; Paul Ransom, Antonio Gramsci, A New Introduction, Hempstead, HarvesterWheatsheaf, 1992, s.135.

44 Stephen Gill ve David Law, "Global Hegemony and the Structural Power of Capital”, Stephen Gill (der.), Gramsci, Historical Materialism and International Relations, Cambridge, Cambridge University Press, 1993, s. 93.

45 Gramsci, Selections From the Prison Notebooks, s. 328.

46 Chantal Mouffe, "Hegemony and Ideology in Gramsci", Chantal Mouffe (der.), Gramsci and Marxist Theory, Londra, Routledge, 1979, s.181; Stuart Hall, Thatcherism and the Crisis of the Left: the Hard Road to Renewal, Londra, Verso Press, 1988, s. 165.

47 JamesH.Mittelman, "WorldOrderStudiesandInternationalPoliticalEconomy”, Alternatives, Cilt9, No3,1983, s.331.

48 Alan Cassels, Ideology and International Relations in the Modern World,Londra, Routledge, 1996, s.2-8.

49 William I. Robinson, Promoting Polyarchy: Globalization, US Intervention and Hegemony, Cambridge, Cambridge University Press, 1996, s. 21-22.

50 Enrico Augelli ve Craig N. Murphy, "Gramsci and International Relations: A General Perspective and Example from Recent US Policy Toward the ftird World”, Stephen Gill (der.), Gramsci, Historical Materialism and International Relations, Cambridge, Cambridge University Press, 1993, s.130. 
rı, daima hem zora hem de rızaya dayalı unsurları birleştirirler. Bu iki form yalnızca metoda ilişkin hedefler için teorik soyutlamalarda birbirinden ayrılabilen, sosyal hâkimiyet ilişkileri içindeki farklı anlardır. ${ }^{51}$ Hegemonik bir yapıda ise sosyal düzen, rızaya dayalı sosyal kontrol araçlarına daha fazla yer verme yoluyla yeniden üretilmektedir. Bu yüzden Gramşiyan hegemonya, “zorun zırhıyla korunan konsensüs"tür. ${ }^{52}$

Gramsci, iki unsurun bir aradalık ve farklılı̆̆ını izah etmek için, Machiavelli'nin rıza ve zorlamanın gerekli şartlarını üzerinde toplayan yarı insan, yarı hayvan Centaur'unu kullanmaktadır. ${ }^{53}$ Machiavelli'nin Centaur'uyla ilgili olarak yaptı̆̆ı bir analojide, kuvvet ve rızanın birlikteliğini "çifte perspektif” kavramıla açıklamaktadır: "Çifte perspektif, kendisini en temelden en karmaşığa kadar değişikşsekillerdeifade edebilir. Ama bunlarteorikolarakMachiavelli’nin Centaur' una tekabüledeniki temel düzeye indirgenebilir; yarı hayvan, yarı insan. Bunlar gücün ve rızanın, otoritenin ve hegemonyanın, vahşetin ve medeniyetin düzeyleridir." ${ }^{54}$

Gramsci, güce ve rızaya dayalı idare arasındaki farklılığı ise üstünlüğ̈̈n iki ideal tipi, "hakimiyet", yani gücün yönetilenlerin eleştirel rızaları olmadan doğrudan uygulanması ile "ahlakî hegemonya/entelektüel ve moral liderlik" 55 arasındaki tezatı ortaya koyarak şöyle tarif eder: "Bir sosyal grubun üstünlüğü kendisini 'hakimiyet' ile 'entelektüel ve moral liderlik' olmak üzere iki şekilde ortaya koyar. Bir sosyal grup yok etme ya da boyun eğdirme eğiliminde olduğu uzlaşmaz grupları hâkimiyeti altına alır, akraba/çok yakın ve müttefik gruplara ise liderlik eder." ${ }^{56}$

Lider grup etrafinda oluşan istikrarlı koalisyonları Gramsci "tarihsel blok" olarak adlandırmaktadır. ${ }^{57}$ Blokların tarihselliği, kendilerini var eden özel koşul ve dinamiklerin ürünüdür. Tarihsel blokları var eden şartlar arasında gruplar arası münasebetlerin yanı sıra, gruplar ile mümkün olanın sınırlarını belirleyen yapılar arasındaki ilişkiler de yer almaktadır. Gruplar, hegemonyacı olmak ya da mevcut konumlarını muhafaza edebilmek için ekonomik, siyasi ve kültürel düzeylerde elverişli şartlara ihtiyaç duymaktadırlar. ${ }^{58}$ Gramsci, tarihsel blokları oluşturup hegemonyacı mücadeleye girişen grupların başarı şanslarını, ekonomik açıdan üretim ilişkilerindeki konumlarına bağlamaktadır. Bu yüzden Augelli ve Murphy, sanayi toplumlarında ancak üretim tarzı içerisinde temel bir rol ifa eden sosyal grupların hegemon olabileceğine dikkat çekmektedirler. ${ }^{59}$ Buna karşılık, Gramsci'nin indirgemecilik karşısındaki entelektüel tavrıyla uyumlu olarak tarihsel bloklar, sadece maddî unsurlar üzerinden tanımlanmamaktadır. Bir tarihsel bloğun oluşumunda ulusal ve küresel düzeydeki ideolojik iklim de etkilidir. Özellikle, medya ve eğitimdeki gelişmeler uzun vadede büyük öneme sahiptirler. ${ }^{60}$ Buyüzden Gramşiyan tarihselbloğu, “maddî, kurumsal,öznelerarası, teorikveideolojik kapasitelerin

51 Robinson, Promoting Polyarchy, s. 22.

52 William I. Robinson, "Globalization, fte World System and Democracy Promotion in US Foreign Policy”, Theory and Society, No25,1996, s. 628.

53 Gramsci, Selections From the Prison Notebooks, s. 169-170; Cox, "Gramsci, Hegemony and International Relations”, s.52.

54 Gramsci, Selections From the Prison Notebooks, s.169-170; Niccolo Machiavelli, The Art of War and The Prince, Henry Neville ve W.K. Marriott (çev.), Texas, El Paso Norte Press, 2005, s. 259. Bir “değişim” teorisyeni olarak bilinen Gramsci ile "realist” politikanın klasikleri arasında sayılan Machiavelli arasındakiilişkiilk bakışta garipsenebilir. Ancak Gramsci”ye göre Machiavelli, ütopist bir hayalci ya da statüko içinde hareket eden bir diplomat değil, “değişim”i tedbirle savunan bir gerçekçidir. Bkz. Finocchiaro, Gramsci and the History of Dialectical Thought, s.143.

55 Augellive Murphy, “Gramsciand International Relations”, s. 127-128.

56 Gramsci, Selections From the Prison Notebooks, s. 57

57 Ibid., s.366.

58 Jonathan Joseph, Hegemony, A Realist Analysis, Londra, Routledge, 2002, s. 125.

59 Augellive Murphy, “Gramsciand International Relations”, s. 130.

60 Gillve Law, "Global Hegemony and the Structural Power of Capital”, s.112. 
bütünleşmesi sonucunda siyasi ve sivil toplum arasında ortaya çıkan organik ilişki” şeklinde daha kapsamlı bir tanımlamaya tabi tutmak mümkün gözükmektedir. Yeni tarihsel blok, yalnızca sivil toplum ve ekonomide güç kazanmakla yetinmemekte, siyasi ağlar ve örgütlenmeyi destekleyecek ikna edici fikirve argümanlara, yani “ahlakî-siyasî düzey” i gerçekleştirecek araçlara daihtiyaç duymaktadır. ${ }^{61}$

Ahlakilik, Gramşiyan hegemonyacı düzen açısından özel bir anlama sahiptir. Daha önce de değinildiği gibi, Gramsci bir toplumsal grubun iktidarının hâkimiyet ile ahlâki hegemonya/entelektüel ve moral yönetim olmak üzere iki şekilde tezahür edebileceğini söylemektedir. Hâkimiyet ile yönetim arasında temel bir ayrım yapan Gramsci'ye göre, ${ }^{62}$ hâkim grubun yönetici konumunu kazanmas1, yüksek bir senteze, "kolektif irade"yi temsil eden entelektüel ve ahlakî liderliğe erişmesine bağlıdır. ${ }^{63}$ Ahlakî hegemonyanın mümkün olması için ise idare öncelikle, ikincil unsurların çıkarlarının sistem içerisine dâhil edilmesiyle sağlanacak genel bir meşruiyet ve aktif rızaya dayanmalıdır. ${ }^{64}$

Hegemonya ahlakîolmadığında, hileve aldatma üzerinekurulduğunda Gramscibunu hâkimiyetin bir şekli olarak kabul etmektedir. ${ }^{65}$ Gramsci'ye göre hilekârlık ve rüşvet gibi yollar gücü korumak için yapılan mücadelede kullanılan taktik silahlardır. Fakat bunlar gücün değil, zayıflı̆̆ın ifadesidirler. ${ }^{66}$ Ahlaki hegemonyaya yönelen hareket ise, aktif rızayı sağlamakiçin hâkim ve ikincil gruplar arasında olduğu gibi hâkim grupların kendi aralarındakiilişkilere aracılık eden mutabakat yaratma sürecini de işletmek zorundadır. ${ }^{67}$ Gramsci'deki yapı-aktör ilişkisini anlatırken değindiğimiz "arınma” burada devreye girmekte ve söz konusu süreçte yapıdan karmaşık üst yapılar alanına geçilmektedir. Sürecin temel niteliği, kurumlar inşa edilirken ve ideoloji geliştirilirken bir grup ya da sınıfın özel çıkarlarının aşılmasıdır. Ĕ̆er söz konusu kurum ve ideolojiler ahlâki bir hegemonyayı yansıtacaklarsa, şekil itibariyle evrensel olmak, belirli bir s1nıfınmış gibi gözükmemek ve hegemonyacı sınıfın hayatî çıkarlarını korurken, liderliğini desteklemeyen ikincil gruplara da bir miktar tatmin sağlamak durumundadırlar. ${ }^{68}$

Bir başka ifadeyle, ahlâkî hegemonyanın kurulmasının gerekli olan şartı, dar ekonomik çıarların daha evrensel bir bakış açısı ya da ideoloji içinde eritilmesi ile lider grubun sosyal vizyonuna katılım sürecinde ikincil gruplara somut tavizler verilmesidir. ${ }^{69}$ Bundan dolayı hegemonya, yönetici grubun ekonomik-korporatif nitelikte özverilerde bulunmasını da beraberinde getirmektedir. Fakat Gramsci'ye göre bu tür özverilerin ve böyle bir uzlaşmanın işin özüyle ilgili olmayacağı da kesindir. Çünkü hegemonya ahlâki-siyasi olduğu kadar ekonomiktir ve yönetici grubun ekonominin kilit kesimlerinde yerine getirdiği karar alıcı işleve dayanmaktadır. ${ }^{70}$

Gramsci, burjuvazinin hegemonyayı sağlayamadığı için hâkimiyetle yetinmek zorunda kaldığ1, iktidarın alt kesimler tarafindan meşru kabul edilmediği düzenlerde ise idarenin çok daha zayıf ve is-

61 Ibid., s. 94.

62 Gramsci, Selections From the Prison Notebook, s.57, 59, 80, 169-170. Harold Entwistle, Antonio Gramsci: Conservative SchoolingforRadicalPolitics, Londra, Routledge, 1979, s.12.

63 Ernesto Laclau ve Chantal Mouffe, Hegemony and Socialist Strategy, Towards a Radical Democratic Politics, Londra, Verso, 1990, s.67.

64 Gill, "Epistemology, Ontology and the ItalianSchool”, s. 40.

65 AugelliveMurphy, "Gramsciand International Relations”, s. 128.

66 GiovanniArrighi, “fteftreeHegemonies ofHistoricalCapitalism”,Stephen Gill(der.), Gramsci, HistoricalMaterialism and International Relations, Cambridge, Cambridge University Press, 1993, s. 149.

67 Robinson, Promoting Polyarchy, s.22.

68 Cox, "Gramsci, Hegemony and International Relations", s.58.

69 David Forgacs ve D. Sternbach (der.), An Antonio Gramsci Reader: Selected Writings, 1916-1935, New York, Schocken Books, 1989, s.190-200.

70 Gramsci, Selections From the Prison Notebooks, s. 161. 
tikrarsız olduğuna işaret etmektedir. Böyle durumlarda yönetim kuvvete dayanarak sürdürülmeye ve zayıf güç temeli desteklenmeye çalışılmaktadır. ${ }^{71}$

Hegemonyaya ahlakilik kazandırılarak zora duyulan ihtiyacın azaltılmasında ise entelektüellere önemli görevler düşmektedir. Gramsci’nin entelektüel liderliğin önemine yaptığı bu vurgu, bilgi edinme süreçleri ve bunların işlevleri hakkındaki düşüncelerinin ışığında daha iyi kavranabilmektedir. Gramsci, bilgi üretim teorisini kimlik ve çıkarlarla ilişkilendirerek, en azından bu anlamda, teorinin nasıl her zaman birileri ve bir amaç için olduğunu göstermektedir. ${ }^{72}$ Gramsci'ye göre gerçeğin anlaş1ması ve bilginin edinilmesi ahlakî, kültürel ve ideolojik prizmalar ya da filtreler yoluyla olmakta; bu sayede toplum şekil ve anlam kazanmaktadır. Bu yüzden hegemonya belli bir bilgi yapısının ve değerler sisteminin inşası anlamına gelmekte, kendi bilgi ve değer sistemini yaratıp bunları genel ve evrensel olarak kabul edilebilir kavramlar haline dönüştürebilen sosyal grup yahut sınıf da entelektüel ve ahlaki liderliğe ulaşmaktadır. ${ }^{73}$

Bu noktada da, bilginin üretilmesi ve kitlelerin eğitilmesi fonksiyonlanını yürüten organik entelektüellere duyulan ihtiyaç ortaya çıkmaktadır. Entelektüeller “organik”tir, zira Gramsci'ye göre bağımsız bir entelektüeller sınıfı yoktur. Her sosyal grup kendi entelektüel tabakasına sahiptir ya da böyle bir tabaka meydana getirme eğilimindedir. ${ }^{74}$ Hegemonyacı sinıfin entelektüelleri beraberce ahenkli bir dünya görüşü oluşturabilecek felsefî, siyasî ve ekonomik bir teori ile disiplinler arasında aktarılabilecek prensipler inşâ etmek zorundadırlar. ${ }^{75}$ İdeolojik mücadele ortamında hakim sınıfin entelektüelleri, daha ikna edici ve sofistike teoriler ortaya koymalı, diğer entelektüelleri hegemonyacı dünya görüşü ve hegemonun hedefleriiçinde eriterek, onlar üzerinde de hakimiyet kurmalıdırlar. ${ }^{76}$

Gramsci, organik entelektüelleri “meşrulaştırma uzmanları” şeklinde tarif etmektedir. Bunlar yönetici grubun kültürüyle, ikincil kitlelerin kültürleri arasındaki çelişkiyi çözerek, mevcut güç yap1sını müttefik ya da ikincil gruplar için kabul edilebilir kılmaktadırlar. ${ }^{77}$ Entelektüellerin fonksiyonları yalnızca belli bir hayat tarzını ve dünyanın bir tanımını yaratmak değil, aynı zamanda bir sosyal grubun çıkarlarıyla değerlerini genel ve ortak değer ve çıkarlar olarak tercüme etmektir. ${ }^{78}$ Bir başka ifadeyle, hegemonyacı sınıfa organik bir biçimde bağlı bulunan entelektüeller, hizmet ettikleri grubun arzularının toplumun tümünün çıkarlarıyla uyumluluk arz ettiğini bilginin her alanında göstermektedirler. ${ }^{79}$

Bilgi üretiminin yanı sıra eğitim için de organik entelektüellere ihtiyaç duyulmaktadır. Zira her hegemonyacı ilişki zorunlu olarak bir eğitim ilişkisidir ve yalnızca değişik sosyal grupların rekabet halinde bulundukları ulusal toplumlar içinde değil, uluslararası alanda ulusal kompleksler ve kıtasal medeniyetler arasında da cereyan etmektedir. ${ }^{80}$ Bireysel düzeyde ise, Gramsci'nin temel insan güdüleri anlayışıyla hegemonyacı “eğitim” süreçleri arasında önemli bir ilişki mevcuttur. Gramsci’ye göre temel insan güdülerinin hiçbiri herhangi bir durumda aniden operasyonel hale gelmemektedir. Insan-

\footnotetext{
71 Hobson, The State and International Relations, s.129.

72 Gill, "Epistemology, Ontology and the Italian School”, s. 23-24.

73 Robinson, Promoting Polyarchy, s.42.

74 Merrington, "fteory and Practice in Gramsci's Marxism”, s. 167.

75 Gramsci, Selections From the Prison Notebooks, s.403.

76 Ibid., s. 229-239.

77 Benedetto Fontana, HegemonyandPower, On The Relation Between Gramsciand Machiavelli, Minneapolis, University of Minnesota Press,1993, s. 140.

78 Ibid., s. 141; “fteory and Practice in Gramsci's Marxism”, s. 153.

79 Augellive Murphy, “Gramsciand International Relations”, s.131.

80 Gramsci, Selections From the Prison Notebooks, s. 240 -241.
} 
lar, bireysel çıkarlarının şuuruna kolektif arzularında olduğu gibi diğer insanlarla etkileşime geçerek, öğrenme yoluyla varmaktadırlar. Çünkü Gramsci'nin karmaşık insanları, nadiren sadece dar anlamda rasyoneldirler. İnsanlar yalnızca sezgi ve moral yargılarda bulunma kabiliyetlerine sahip değillerdir, aynı zamanda normal şartlar altında insan düşünceleri karmaşık bir şekilde irrasyoneldir. Bu yüzden, insanlığın çelişen şuuru, eğitmenlik yapacak kadrolara muhtaçtır. Ancak bunlar sayesinde şuurlardaki rasyonel olmayan halleri temizlemek ve insanların kolektif çıkarlarını fark etmelerine yardımcı olmak mümkündür. ${ }^{81}$

Görüldüğü üzere, bilgi üretimi ve eğitim, hem devlet iktidarını elinde tutan tarihsel bloğun hem de karşı hegemonya oluşturmak için yeni bir tarihsel blok inşâ etmeye çalışan grupların sivil toplum zemininde yürüttükleri mücadelede önemli işlevlere sahiptirler. Bu mücadelenin niteliğinin daha net bir şekilde ortaya konabilmesi için Gramsci'nin sivil toplum, devlet ve bunlar arasındaki ilişkilere yaklaşım biçimini de ele almak gerekir.

İlk adım olarak Gramsci'nin analizlerinin tarihsel bağlamını, 19. yüzyılın sonu ve 20. yüzy1lın başında ileri derecede kapitalistleşmiş, sivil toplumun geliştiği, kapitalist sınıf gücünün toplumun kültürel kurumlarına ve nihayetinde devlet ve onun zor kullanma aygitına nüfuz ettiği Batı toplumlarındaki siyasi ve ideolojik mücadele ortamının oluşturduğu hatırda tutulmalıdır. ${ }^{82}$ Gramsci'nin problematiği de, bu özel zeminin başarılı bir iktidar stratejisinin hayata geçirilebilmesine imkân verecek şekilde analiz edilmesidir.

Gramsci, siyasi eylemin içinde gerçekleştiği iki önemli üst yapı düzeyi olarak gördügü sivil toplum ve devlet hakkındaki değerlendirmelerinde, bağlam değişikliğinden kaynaklanan özgünlükleri hem zaman hem de mekân farklılaşmalarını dikkate alarak vurgulamaktadır. ${ }^{83}$ Bu yüzden Gramsci'nin yazılarında ilk bakışta birbirleriyle çelişir gibi gözüken üç farklı devlet tarifi bulunmaktadır. ${ }^{84}$ Bunların ilkinde devlet, sivil toplumla zıtlığı esasında tanımlanmaktadır. Fakat, bu tarz bir devlet-sivil toplum ilişkisinin mekânı Avrupa değildir: "Doğuda devlet her şeydir, sivil toplum ilkel ve jelatinlidir; Batı'da devlet ve sivil toplum arasında uygun bir ilişki vardır ve ne zaman devlet sıkıntıya düşse güçlü sivil toplum yapısı derhal ortaya çıkar. Devlet yalnızca dış hendektir, ardında güçlü bir istihkâm ve siperler sistemi durmaktadir." ${ }^{85}$

Devletin sivil toplumu kuşattığını ve devletin sivil toplumla özdeş kabul edilebileceğini söylediği pasajlarda ise mekân olarak Avrupa'yı işaret ederken, farklılıkların kaynağı muhtelif hegemonik güç kombinasyonları tarafindan sivil toplumla kurulan ilişkinin değişik ânlardır. İlk durumda, "Devlet

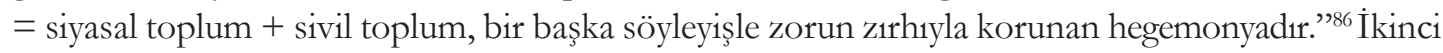
durumda ise, "devlet yalnızca hükümet aygıtı olarak değil, aynı zamanda hegemonya ya da sivil toplumun özel aygıtı olarak anlaşılmalıdır. Gerçekte sivil toplum ve devlet bir ve aynı şeydir.” 87

Devlet, diktatörlük + hegemonya ve siyasî toplum + sivil toplum şeklinde tanımlandığında, bu iki düzey bir yandan hâkim grubun toplum üzerinde uyguladığı hegemonyaya, diğer yandan da dev-

\footnotetext{
81 Augellive Murphy, “Consciousness, Myth and Collective Action”, s. 37.

82 Gramsci,Selections From the Prison Notebooks, s. 235-239,258-263.

83 Ibid., s. 262.

84 Çelişkitezinisavunanlaraörnekolarakbkz.PerryAnderson, “fteAntinomies of Antonio Gramsci”,NewLeftReview,No 100, 1976, s. 12-13.

85 Gramsci, Selections From the Prison Notebooks, s. 238.

86 Ibid., s. 263.

87 Ibid., s. 261, 160.
} 
let ya da icracı hükümet aracıllı̆̆1yla uygulanan "doğrudan hâkimiyet”e tekabül etmektedir. ${ }^{88}$ Devlet vasıtasıyla iktidardaki grup/sınıf yalnızca hâkimiyetini meşrulaştırıp sürdürmemekte, aynı zamanda devleti yönettiklerinin aktif rızasını kazanmakiçin kullanmaktadır. ${ }^{89}$

Sivil ve siyasî toplumun farkl11ıklarını koruyarak bütünleştikleri bu durumda, sosyal kontrol iki seviyede uygulanmaktadır: Sivil toplum ve Gramsci'nin genişletilmiş devleti içinde erimiş olan siyasî toplum. Gramsci'nin genişletilmiş devletinde, hegemonya sivil toplum tarafindan kendi içinde hayata geçirilirken, güç devlet aracıllğıyla, ancak sivil toplumdaki mevcut kuvvetler zinciri esas alınarak kullanılmaktadır. Zora başvurma teşebbüsünü, gazeteler ve dernekler gibi kamuoyu organları, çoğunluğun rızasına dayalıymış gibi göstermektedirler. ${ }^{90}$ Bu noktada Gramsci'nin devlet ve sivil toplum ayrımı tamamen metodolojiktir. Yönetimin sağlanmasında rıza ve zorlama mekanizmaları birbirleriyle kaynaşmaktadır. Siyasal toplum formel devlet ayg1tı şeklinde ele alındığında, Gramsci'nin genişletilmiş devleti, bunun yanında sivil toplumu da kuşatmaktadır. ${ }^{91}$ İleri kapitalizmin iktidar mekanizmalarına zorve rızanın iç ilişkilerine odaklanan bu “çifte perspektif”"ten yaklaşan Gramsci, sivil toplumu siyasal toplumla bağlantılı birşekildeanlamaktadır. ${ }^{92}$

Gramsci bunu yaparken, siyasal toplum ve kurumları sivil toplum zeminine yerleştirmektedir. Gramsci'nin “siyasal toplum”, birçok gerçekçinin devlet olarak gördüğü şeydir. Fakat, gerçekçilerin aksine Gramsci, siyasal toplum ya da “devlet merkezi” ile “organik, daha geniş anlamda devlet” arasındaki ayrıma özel bir önem vermektedir. Gramsci organik anlamda devletle, tamamiyla özel tabiatta gibi görünenlerle birlikte siyasal hayatın temel kurumlarının dâhil olduğu üst yapının tümünü kastetmektedir. ${ }^{93}$

Devletin bu kuşatıcılıkta tanımlanmasının temel sebebi, hükümetin idare, yönetim ve zorlama ayg1tlarına aslında bütün sosyal örgütlenmeye liderlik eden sınıfın hegemonyası tarafından hükmediliyor oluşudur. Bu yüzden devlet, siyasal yapının sivil toplumdaki destekçilerini de içerecek biçimde ele alınmalıdır. Gramsci bunları kilise, eğitim sistemi, basın ve insanlarda hegemonyacı sosyal düzenle uyumlu belirli davranış kalıpları ve beklentiler yaratılmasına yardım eden diğer bütün kurumlar şeklinde sıralamaktadır. ${ }^{94}$ Kitlesel siyasî partiler, medya, ticaret birlikleri ve diğer sivil örgütlenmeler de ikincil sınıfları kapitalist topluma entegre etmektedirler. ${ }^{95}$ Devlet ayrıca, okullar ve mahkemeler gibi organları aracılığıyla sivil toplumda rıza unsurunun pekişmesi için doğrudan faaliyet göstermektedir. Bu yüzden, ordu ve polis gibi baskı araçlarının yanı sıra, meclisler ve eğitim organlarına da sahip olan devlet, basitçe sadece "negatif ve baskıcı" değil, aynı zamanda "pozitif ve eğitici” dir. ${ }^{96}$ Benzer şekilde sivil toplum da bazı zamanlarda hegemonyanın zor unsuruna katılabilmektedir. Militarize olmuş siyasî partiler ve organize dinî gruplar bunun örnekleridir. ${ }^{97}$ Liberal ekonomistlerin daha dar bir çerçevede tanımladıkları “gecebekçisidevlet”veBismarck'lailişkilendirilen “müdahaleci” devlettasavvurlarıyla

88 Ibid., s.12.

89 Ibid., s. 244, 182.

90 Merrington, "fteory and Practice in Gramsci's Marxism",s.154.

91 Robinson, Promoting Polyarchy", s. 28.

92 Mark Rupert, "Alienation, Capitalism and the Inter-State System: Towards a Marxian/Gramscian Critique", Stephen Gill (der.), Gramsci, Historical Materialism and International Relations, Cambridge, Cambridge University Press, 1993, s. 78-79.

93 Augellive Murphy, “Gramsciand International Relations", s.129.

94 Gramsci, Selections From the Prison Notebooks, s. 261;Cox, "Gramsci, Hegemony and International Relations", s. 51; Rupert, "Alienation, Capitalism and the Inter-State System", s. 79; Joseph V.Femia, Gramsci's Political Thought: Hegemony, Consciousness and the Revolutionary Process, Oxford, Clarendon Press, 1981, s. 25-26.

95 Robinson,Promoting Polyarchy,s. 28.

96 Ibid., s. 28.

97 Femia, Gramsci's Political Thought, s. 28. 
tezat oluşturan Gramsci'nin bu devlet anlayış1, ${ }^{98}$ tarihsel olarak devlet ve sivil toplum arasında sık sık organik bütünleşmenin yaşandığ1 Anglo-Saxon ülkelerinde rastlanan “yayg1n” ve "bütüncül” yapıyla yakınlıklar taşımaktadır. ${ }^{99}$

Gramsci’ningenişlemiş devletinin içinde siyasal toplumla kaynaşan sivil toplum, kimlik oluşumunun, ideolojik mücadelenin, entelektüellerin faaliyetlerinin ve ahlakî ya da hilekârllğa dayalı hegemonyanın mekânıdır. Kişinin şuur kazanarak ilk kez siyasal faaliyetle ilgilendiği bağlam olan sivil toplumda çıkarlar bir araya gelmekte, dar çıkarlar ideolojiler gibi daha evrensel görüşlere dönüştürülmekte ve ittifaklar kurulmaktadır. ${ }^{100}$ Burjuvazinin hegemonyasını sürdürdüğü bu alan, karşı hegemonyaların inşa edilebileceği mücadele zeminidir. ${ }^{101}$ Gramsci'nin sivil topluma müesses bir hegemonyacı yapı içinde biçtiği rol, sivil toplumun devlet hâkimiyeti ve toplumdaki gruplar arasında bir tampon olduğuna ve sınıf ile grup hâkimiyetinin sivil toplum geliştikçe hafifleyeceğine dair görüşlerle tezat teşkil etmektedir. ${ }^{102}$

Nitekim, Gramsci’ye göre hakim sınıf hegemonyasının sivil toplumdan yükselen güçlerin meydan okumalarıyla zayıfladığını gördüğünde, "pasif devrim” gibi değişik taktiklerle iktidarını korumaya çalışmaktadır. ${ }^{103}$ Yönetici sınıf, aşağıdan gelen baskılarla mücadele edebilmek için verdiği tavizlerle sivil toplumu yeniden organize etmektedir. Bu sayede kitlelerin kendi siyasi talepleri doğrultusunda yapacakları faaliyetlerin önü alınmaktadır. ${ }^{104}$ Nitelikli insan gücüyle geleneksel idareci sınıf, muhaliflerden daha büyük bir hızla kadro ve programlarını değiştirerek, kaybetmeye başladığı kontrolü yeniden ele geçirebilmektedir. ${ }^{105}$ Pasif devrimler, birbirini takip eden küçük reform dalgaları ya da aydın despotizmi tarzı müdahalelerle, kitlelerin katılımı olmaksızın yukardan gerçekleştirilmektedir. ${ }^{106} \mathrm{Bu}$ esnada muhalif sınıflar, kendilerini az ya da çok örtülü bir zeminde uzlaşmak zorunda hissettikleri yavaşçailerleyen "moleküler” bir sosyal değişiminiçinde bulmaktadır. ${ }^{107}$

Pasif devrim ihtiyacını doğuran ulusaşırı gelişmelere dikkat çekişinden de anlaşılacağı üzere, ulusal ölçekteki siyasi mücadelelerin ulusaşırı bağlamlarını önemseyen Gramsci, uluslararası sistemin karakterinin temel belirleyicisi olarak sosyal ilişkileri görmektedir. ${ }^{108}$ Bir başka ifadeyle, ulusal düzeyde siyasi dengelerin ana belirleyicisi nasıl sivil toplumdaki sosyal ilişkiler ağı ise, uluslararası sistemin niteliği de aynı zeminde şekillenen dinamikler tarafından tayin edilmektedir.

Gramsci'nin iktidar üzerine yaptığı sosyolojik analizlerde kullandığı anahtar kavramı adlandırmak için hegemonya kelimesini tercih edişinde, ulusal ve ulusaşırı arasındaki bu geçişken etkileşimin pay sahibi olduğunu düşünmek mümkündür. Tarihsel olarak devletlerarası ilişkiler bağlamında kullanılan hegemonyanın etimolojik ve yan anlamları arasında liderlik ve hakimiyet bulunmaktadır.

98 Gramsci, Selections From the Prison Notebooks, s. 257-263.

99 Ibid., s.12.

100 Augellive Murphy, “Gramsciand International Relations”, s. 129.

101 Robert W. Cox, "Civil Society at the Turn of the Millenium: Prospects for an Alternative World Order", Review of International Studies, Cilt 25, No 1, 1999, s. 3-28.

102 Robinson, Promoting Polyarchy, s. 29.

103 Pasif devrim kavramı üzerine detaylı bir inceleme için bkz. Anne Showstack Sassoon, Gramsci ’s Politics, Minneapolis, University of Minnesota Press, 1987. Gramsci’nin pasif devrim kavramını kullandığı değişik bağlamlar için bkz. Cox,

"fte International in Evolution", s. 519.

104 Joseph, Hegemony, A Realist, s.125, 138.

105 Gramsci, Selections From the Prison Notebooks, s. 210.

106 Ibid., s. 115.

107 Kees van der Pijl, “Transnational Class Formation and State Forms”, Stephen Gill ve James H. Mittelman (der.),

Innovation and Transformation in International Studies, Cambridge, Cambridge University Press, 1997, s. 128.

108 Gramsci, Selections From the Prison Notebooks, s. 176. 
Aristo'nun çalışmalarına bakıldığında, kelimenin etimolojik köklerinin yattığı Eski Yunan'daşehir devletleri arasındaki ilişki biçimlerini tasnif için emperyalizm ve hegemonyacı liderliğin birbirlerinden ayrıldıkları görülmektedir. ${ }^{109}$ Bu noktadan hareketeden Arrighi de, Gramsci'nin hegemonyayı Uluslararası İlişkilerle analoji yoluyla sosyal gruplar arasındaki münasebetleri açığa çıkarmak için kullanmış olabileceğini düşünmektedir. ${ }^{110}$

Bu durumda Cox’un, Gramsci'nin kavramlarını Uluslararası İlişkilere uyarlarken onun izlediği zihni süreci tersine çevirdiğini, ulusaşırı ve uluslararasının anlaşılması için ulusal düzenlerin analizinden devşirdiği kavram dizilerine başvurduğunusöylemek mümkündür.

\section{Hegemonya: Cox ve Küresel İktidarın Sosyolojisi}

Cox'un hegemonya kavramını Uluslararasıİlişkilere uyarlarken öncelik verdiğiiki ana unsurşu şekilde tanımlanabilir: İktidarın somut güç temelinin yanı sıra idare edilenlerin meşruiyete tercüme edilecek rızasına duyduğu ihtiyaca yapılan vurgu ve devletin değişmez nitelikler etrafında tanımlanan dondurulmuş bir imaj üzerinden değil de, sosyal kuvvetlerin karmaşık etkileşimleriyle birlikte sivil toplumdaki mücadele ve dinamiklerin seyrine göre şekil kazanan bir zatiyet halinde ele alınış1.

Hegemonyay1, dünya tarihinin değişik dönemlerinde örneklerine rastlanan hâkimiyet biçimlerinden ayıran temel nokta, ikincil devletlerin hegemonun liderliğine yalnızca maddi güç kaynaklarının yarattı̆̆ı baskıyla değil, çı kar algılamalarındaki ortaklaşmanın da etkisiyle rıza göstermeleridir. Bir başka ifadeyle, gücünün bazı yahut tüm devletlere nispetle artmasının diğerlerinin vatandaşlarının genel çıkarına da uygun düşeceği kanaatini uyandıracak derecede güvenilirlik kazanan devlet, dünya hegemonu olabilmektedir. ${ }^{11}$ Güvenin kazanılması önemlidir, zira hareket kabiliyetleri tarihsel yapıların çerçevesini çizdikleri mümkün olanın algılanma sınırları tarafindan baskılanıyor olsa da, hegemonya karşısında tavır belirleyecek insanlar şuur ve özgür irade sahibidirler. ${ }^{112}$

Coxcu bir hegemonyanın üzerine oturduğu fikir, maddi kabiliyet ve kurumlardan oluşan üçlü sacayağından fikir, rızanın sağlanmasında hayati işlev görmektedir. Bu yüzden, Cox’a göre bir devletin ekonomik, sosyal ve siyasi temel kurum ve örgütlenme şekillerini ikincil devletlerin taklit etmeleri hegemonyanın oluşumu için yeterli olmamakta, anahtar değerlerinin de bir benzeşme modeli haline gelmesi gerekmektedir. ${ }^{113}$ Hegemonya, devletler ve devlet dışı unsurların meydana getirdikleri yapılar bütününe nüfuz eden, düzenin doğası hakkındaki değerler ve anlayış biçimi şeklinde tarif edilmekte, bunların görece istikrarı ile sorgulanamazlık derecesi de sistemin hegemonik niteliğinin ölçüsü kabul edilmektedir. ${ }^{114}$ Mümkün olanın algılanma sınırlarına işaret eden sorgulanamazlık, hegemonun

109 Konuyla ilgili tartışmalar için bkz. Shalom Perlman, "Hegemony and Arkhe in Greece: Fourth-Century B.C. Views", Richard Ned Lebow ve Barry S.Strauss (der.), Hegemonic Rivalry: From Thucydides to the Nuclear Age, Boulder, Westview Press, 1991,s. 269-86; William ScottFerguson, GreekImperialism, New York, Biblo\&TannenPublishers, 1981, s. 19-22; Aristotle, The Politics of Aristotle, Ernest Barker (çev.), Oxford, Clarendon Press, 1948, s. 319.

110 Arrighi, "fte ftree Hegemonies”, s.150. Gramsci’nin "büyük politika-küçük politika” sınıflandırması da Uluslararası İlişkilerle yerel politika arasında kurduğu ilgiyi açıkça göstermektedir. Finocchiaro, Gramsci and the History of Dialectical Thought, s. 138-139.

111 Arrighi, "fte ftree Hegemonies", s. 151.

112 Gill, "Epistemology, Ontology and the Italian School”, s. 43.

113 Cox, "Gramsci, Hegemony and International Relations", s. 62.

114 Robert W. Cox, “Towards a Counterhegemonic Conceptualisation of World Order", Notes Prepared for the Governancewithout-Government Workshop, California, 1990, Aktaran: Stephen Gill, "Epistemology, Ontology and the Italian School", s. 42. 
öngörülen tepkilerine göre belirlenen rasyonel kısıtlamaların değil, böyle bir hesaba dayanılmaksızın değerlerin doğalve kaçınılmaz hissedilecek kadar içselleştirilmesinin sonucudur. ${ }^{115}$

Pek çok aktöre doğalmış gibi gözüken bu özneler arası anlamlar yapısını, hegemon devletin hâkim olduğu maddi güç temeli desteklemektedir. Cox hegemonik dünya düzeninin dayandığı maddi kabiliyetleri, aynı zamanda hem üretici hem de yıkıcı potansiyellere sahip teknolojikve örgütsel kabiliyetler, üretici ve yıkıcı potansiyellerin teknolojinin dönüştürebileceği doğal kaynaklar şeklinde biriktirilmiş halleri, sanayi tesisleri ve askeri techizat gibi ekipman stoklar1ile bunları yönetebilecek refah şeklinde sıralamaktadır. ${ }^{116}$ Hegemonyacı dünya düzeninin ayırt edici özelliği oydaşma olsa da, söz konusu maddi kabiliyetlerin yarattığı zorlama imkânlarına yaslanan siyasî, askerî, ekonomik ve psikolojik unsurların hepsi hegemonik ilişkide mevcut ve önemlidir. ${ }^{117}$ Zorlama potansiyeli maddi güç ilişkilerinin bünyesinde yer almakta, güçlü gerekli durumlarda zayıf tarafa iradesini dayatabilmektedir. ${ }^{118}$

Buna karşlık, zora başvurma ile sistemin hegemonyacı niteliği arasında ters orantı vardır. Hegemon, liderlik misyonunu sadece kendi özel çıkarlarının gereği olarak değil, ikincil devlet ve grupların çıkarlarını da gözeterek rızalarını almaya imkân verecek evrensellikle temellendirebildiğinde, itaati sağlamak için zora başvurma ihtiyacı kalmayacaktır. Her zaman varlığını hissettirse de, hegemonyacı ilişkide gücün bilinçlerdeki yeri, rızaya göre çok daha geridedir. Aksi olduğunda, yani güçlü rıza aramaksızın zor kullanarak itaati sağlamaya ve özel çıkarlarını bu yolla kollamaya başladığında iktidar ilişkisi hegemonyacı olma vasfinı yitirecektir. ${ }^{119}$ İlk durumda liderlik hegemonyacı iken, ikinci durum zamanla hegemonun gücünükorumasını sağlamak biryana, rekabetiteşvik ederek, karşı hegemonyacı kuvvetler zincirini ${ }^{120}$ tetikleyeceğiiçin “kendine karşıliderlik” olarak tanımlanmaktadır. ${ }^{121}$

Hegemonyacı dünya düzeninin üçüncü sacayağında yer alan kurumlar, fikirler ve maddi güç unsurlarının özel bir bileşimi ile hayat kazanmakta, daha sonra hem fikirlerin hem de maddi kabiliyetlerin gelişimini etkilemektedir. Temel görevleri bir taraftan hegemonun siyasi-ekonomik projesini meşrulaştırıp savunurken, diğer yandan da sistemin istikrara kavuşarak ebedileşmesinin yolunu açmaktır. ${ }^{122}$ Ancak tarihlerinin ilk evrelerinin ardından kendi hayatlarını yaşamaya başlayan kurumlar, zıt eğilimlerin savaş alanı haline dönüşebilmektedir. Ayrıca, zaman içinde aynı alanda farklı eğilimlerin temsil edildiği rakip kurumlar da oluşabilmektedir. ${ }^{123}$

Maddi kabiliyetler, fikirler ve kurumların meydana getirdikleri hegemonik üçgen, birer sosyal, ekonomik ve siyasi yapıyla somutluk kazanmakta, bunlardan yalnızca bir tanesine dayanılarak hayat bulamamaktadır. ${ }^{124}$ Cox'un söz konusu yapılanın şekillenişine yaklaşımı, Uluslararası İlişkilere aktardığ1 ikincitemel Gramşiyan perspektifdoğrultusundadır. Sosyal, siyasi ve ekonomik yapıların oluşumlar1 ve etkileri ele alınırken, hegemon da dâhil olmak üzere devletler tektipleştirilmeyip, sivil toplumları ve sosyal kuvvetlerle ilişkileri göz önünde bulundurulmak suretiyle değerlendirilmekte; ayrıca ulusaşır1 güçler de analizlere dâhil edilmektedir.

115 Burcu Bostanoğlu, Türkiye-ABD İlişkilerinin Politikası, Ankara, İmge Kitabevi, 1999, s. 197.

116Cox, "SocialForces, States",s.98.

117 Lea Brilmayer,American Hegemony, Political Morality in a one-Superpower World, New Haven\&London, YaleUniversity Press,1994,s.14.

118 Cox, "Social Forces, States and World Orders", s. 99.

119Ibid., s. 99.

120 Gill, "Epistemology, Ontology and the Italian School”, s. 43.

121 Arrighi, "fte ftree Hegemonies”, s. 150.

122 Ian Taylor,StuckinMiddle Gear:SouthAfrica's Post-ApartheidForeignRelations, Praeger, Greenwood,2001,s.11.

123 Cox, "Social Forces, States and World Orders", s. 99.

124 Cox, "Gramsci,Hegemony and International Relations", s.62. 
Örneğin Cox, birbirlerinin türevi ya da tek yönlü belirleyeni şeklinde görmediği, bilakis sistemin diğer unsurlarına etki edecek değişim dinamiğinin herhangi birinden doğabileceğini varsaydı̆̆1 sosyal kuvvetler, devletler ve dünya düzenlerinden oluşan insan faaliyetlerinin muhtelif düzlemleri arasındaki çok yönlü etkileşimi açıklarken, ulusaşırı dinamiklerin oynadıkları hayatî role dikkat çekmektedir. Cox'un politik ekonomi perspektifinden çizdiği dünya portresinde küresel ve yerel ölçekte faaliyet gösteren sosyal kuvvetlerin meydana getirdikleri güç konfigürasyonu önemli yer tutmakta, devletler de otonom nitelikleri vurgulanmakla birlikte, ilişkilere aracıllk etme işlevleriyle büyük resimdeyerbulmaktadırlar. ${ }^{125}$

Sosyal kuvvetlere odaklanma, Uluslararası İlişkiler disiplininin temel tartışma konularından biri olan gücün doğası ve niteliği hakkındaki sorular karşısında yeni-gerçekçiliğin maddi kuvvetleri oluşum süreçlerinin niteliğini dışlayarak birikmiş nihai kapasiteler üzerinden değerlendiren yaklaş1mina alternatif cevaplar üretilmesinin de önünü açmaktadır. Güç sadece bir verilenden ibaret kabul edilmemekte, gücü var k1lan sosyal süreçlerin anlaşılması için çaba gösterilmektedir. ${ }^{126}$ Söz konusu süreçler de, yalnızca ulusal sınırlar içindeki dinamiklerin özerk gelişim şemalarından izlenmemektedir. Örneğin, devletlerarası askeri ve diplomatik ilişkilerin daha geniş bağlamlarından yalıtılmış hallerine odaklanan bir uluslararası sistem tasavvurundan farklı olarak, sosyal ilişkiler etrafında biçim kazanan Coxcu dünya düzenlerindeki önemli bir yapısal değişimin, yerelölçekteki sosyal ilişkileri çerçeveleyen ulusal siyasi düzenlerde de temel bir değişmeye tekabül edeceği varsayılmaktadır. ${ }^{127}$

Etkileşimin diğer yüzünde müesses bir hegemonyacı sistemin, ulusaşırı güçlerin eylem alanlarını çevreleme kabiliyeti bulunmaktadır. Hegemonyayı hayata geçiren kurumlar, evrensel normlar ve hâkim üretim sistemini destekleyen kuralların belirlendiği diğer mekanizmalar, sadece devletlere etkileri bağlamında incelenmemekte, ulusal sınırları aşarak faaliyet gösteren sivil toplum kuvvetlerinin genel davranış tarzlarına tesirleri de kuram içerisinde önemli yer tutmaktadır. ${ }^{128}$

Bir başka ifadeyle, hegemonyanın kaynağını teşkil eden hâkim devletin sivil toplumu uluslararasılaşarak iktidarını kurumsallaştırdığında, meydana getirdiği yapılar hem kendisinin hem de nüfuz edilen devlet-sivil toplum komplekslerinin davranış çerçeveleri üzerinde etki sahibi olmaktadır. $\mathrm{Bu}$ noktada söz konusu çift yönlü etkileşimin oluşum süreçlerive niteliğini daha yakından kavrayabilmek için Cox'un, Gramşiyan çözümlemelere dayanarak kuramına uyarladığı devlet, sivil toplum ve hegemonya arasındaki ilişki demetini ele alış biçimine odaklanmak yararlı olacaktır.

Uluslararası İlişkilerde devleti, önce tüm devletlere uygulanabilecek modellerden hareketle tanımlayıp, daha sonra bu modellerin niteliği hakkında tartışmalar yürüten perspektiflerden farklı olarak; varlık şartları, kurucu prensipleri ve normları zaman içinde değişen muhtelif devlet ve dünya düzeni formları olduğunu ileri süren Cox'un yaklaşımı, ${ }^{129}$ devletin tektipleştirilmesini reddetmekte ve dikkati çeşitliliği doğuran sebeplere yöneltmektedir. ${ }^{130}$ Devletleri birbirlerinden farklılaştıran temel unsur, sivil toplumları ile kurdukları ilişkinin niteliğidir. Dünya düzeninin farklı devlet/sivil toplum komplekslerine etkileri de içerdeki ilişki biçiminin önemli belirleyicilerinden dir. ${ }^{131}$

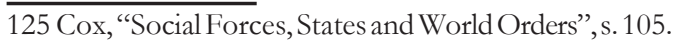

126 Ibid., s.105.

127 Cox, "Gramsci, Hegemony and International Relations", s. 64.

128 Ibid., s. 62 .

129 RobertW.Cox,Production PowerandWorldOrder: SocialForcesinthe Making ofHistory, New York, ColumbiaUniversity Press, 1987, s. 111-211.

130 Markus E. Bouillon, “Gramsci, Political Economy, and the Decline of the Peace Process”, Critique: Critical Middle Eastern Studies, Cilt 13, No 3, 2004, s. 241.

131 Sinclair, "Beyond International”, s. 3. 
Sivil toplumun devleti şekillendirme kabiliyetini öne çıkaran bu bakış açısı, uluslararası politika analizlerinde güç ilişkilerinin yalnızca devletlerarası düzeyle sınırlanarak değerlendirilmesinin yarattığ1 sorunlar karşısında alternatif bir yaklaşım önermektedir. ${ }^{132}$ Bu sayede, dünya hegemonyası inşâ eden gücün, sivil toplum içindeki oluşum süreçlerinden başlanarak, uluslararası sistem ve etki alanı içindeki diğer devlet/sivil toplum komplekslerine kadar uzanan bir çerçevede incelenebilmesi mümkün olmaktadır.

Cox, ilk dönem çalışmalarında farklı ideolojiler ve sosyal kuvvet bileşkeleri üzerine kurulu sivil toplum/devlet komplekslerine örnek olarak Doğu Bloğu'ndaki yeniden dağıtımcı devletlerile Birinci Dünya Savaşı sonrasının yeni-liberal devletlerini göstermektedir. 1980’lere doğru yeniden dağıtımc1 devlet güç kaybederken, yeni-liberal devlet ABD'de Reaganomics ve İngiltere'de Thatcherism ile birlikte güç kazanmıştır. ${ }^{133}$

Bu farklı devlet/sivil toplum kompleksleri, önce ulusal düzeyde şekillenmiş, daha sonra hegemonik nüfuz sahaları oluşturabilmek için birbirleriyle rekabete girişmişlerdir. Cox, ulusal hegemonyanın hem doğuş hem de yayılma sürecini açıklarken, Gramsci'nin tarihsel blok kavramına başvurmaktadır. Hegemonyacı koalisyonun inşasında maddi çıkarlar ve fikirlerin beraberce oynadıkları rollere dikkat çeken Cox'un perspektifi, muhtelif aktörlerin öncelikleri arasındaki uyumun analiz edilmesini kolaylaştırmaktadır. İktidarın kuruluşunda siyasi, ahlakî ve ideolojik faaliyet alanları ile ekonomi arasındaki yanyanalık ve karşılıklı etkileşime yapılan vurgu, aktörlerin bir araya gelişlerinde her şeyin ekonomiye ya da fikirlere indirgenmesinin önüne geçmektedir. ${ }^{134}$

Nitekim hegemon ülkede devlet ile iktidardaki tarihsel bloğun ilişkilerinde, birinciye sosyal kuvvetler karşısında göreli bir otonomi tanıyan Cox, devletin bir bütün halinde hakim sınıfın ekonomik projesiyle uyumlu faaliyet göstermekle birlikte, bu sınıfın unsurlarının özel çıkarlarına cevap vermediğini düşünmektedir. Özel çıkarlar üzerinde yükselen zayıf devletler ise yüksek bir düzenleme gücüne sahip olamamaktadır. ${ }^{135}$

Tarihsel bloğun içerde hegemonyacı liderliğe erişmesi, dünya hegemonyasına giden yolda ilk aşamadır. Cox'un tanımladığı şekliyle dünya hegemonyası, ulus devlet temelli bir karakterle tezahür ettiğinde, en büyük ulusal ekonomi içindeki hâkim gruba ait sosyal kuvvetlerin en güçlü oldukları dönemde yerel düzeyden uluslararası alana yayılışlan ile doğmaktadır. ${ }^{136}$ Hegemonyanın genişleme güzergâhındaki ülkelerin iktidardaki sosyal tabakaları ile hegemonik güce hâkim olan tarihsel blok arasındaki uzlaşı ve bütünleşmeler, hegemonyayı mümkün kılmaktadır. ${ }^{137}$ Bunun gerçekleşebilmesi için, hegemonun diğerlerinin paylaşabileceği evrensel bir vizyon üretmesi ve icap ettiğinde kendi kısa vadeli menfaatlerini göz ardı etmesigerekmektedir. Cox, dünya algılamasındaki evrenselleşmenin, hegemonyacı ülkenin liderlerinin özel ve yerel çıkarlarla çatıştığı durumlarda bile evrensel prensipleri desteklemelerini sağlayacak dereceyeulaşabileceğine dikkatçekmektedir. ${ }^{138}$

132 E. Fuat Keyman, “Eleştirel Düşünce: İletişim, Hegemonya, Kimlik/Fark”, Atilla Eralp (der.), Devlet, Sistem ve Kimlik, Uluslararası İlişkilerde Temel Yaklaşımlar, İstanbul, İletişim Yayınları, 2000, s. 246.

133 Burcu Bostanoğlu, “Uluslararası İlişkilerde Metodoloji Tartışmaları ve Robert W. Cox”, Burcu Bostanoğlu ve Mehmet Akif Okur, Uluslararası Illişkilerde Eleştirel Kuram, Hegemonya, Medeniyetlerve Robert W. Cox, Ankara, Gazi Kitapevi, 2008, s. 34.

134 Cox, “Gramsci, Hegemony and International Relations”, s. 55-56.

135 Cox, Production Powerand WorldOrder, s. 149.

136 Ibid., s. 149.

137 Gill, "Epistemology, Ontology and the ItalianSchool”, s. 42.

138 RobertW.Cox, “Middlepowermanship,JapanandFutureWorldOrder”,InternationalJournal,Cilt44,No4, 1989 , s. 829. 
Cox’a göre hegemonyanın çevreye doğru genişlemesi, pasif devrim biçiminde gerçekleşmektedir. Bu süreçte, hegemonik sisteme eklemlenmeye çalışan toplumlar birçok problemle yüzleşmek durumundadırlar. Zira, eski yapılarını koruyarak hegemonik modelden parçalar almaya çalışan ülkelerin, hegemonla aynı sosyal ve ekonomik süreçlerden geçmedikleri için bazı ekonomik ve kültürel unsurlara uyum şansları bulunsa da, siyasi modelleri benimsemeleri kolay olmamaktadır. ${ }^{139}$

Cox, tarihsel blok kavramının ifade ettiği ittifaklar üzerine kurulu iktidar anlayışına uluslararasının ulusaşırıya dönüştüğü konjonktürde, dünya hegemonyasının zorunlu olarak tek bir devletin inhisarında bulunması gerekmediğini göstermek için de başvurmaktadır. Bir ideoloji ve bu ideolojiyle uyumlu kurumlar aracıllı̆ıyla sağlanan geniş temelli rızanın ayakta tuttuğu hegemonya, bir iktidar yapısıdır. Hâkim olan güç bir devlet ya da devletler grubu olabileceği gibi, devlet ve özel aktörlerin koalisyonundan da oluşabilir. ${ }^{140}$ Cox'un bu açılımı, yeni-Gramşiyan okul yazarlarının 1990’lardan 2000’lere uzanan süreçte küresel yönetişim kavramını eksene alarak yaptıkları çalışmaların ve imparatorluk tartışmalarının da öncülüdür. ${ }^{141}$

\section{Sonuç}

Bu çalışmada, Robert W. Cox’un hegemonya kavramı etrafında incelediği iktidar mantığı, zaman oku üzerinde geriye doğru gidilerek Gramsci'nin yazılarındaki entelektüel köklerinin ışığında değerlendirilmiştir. Giriş bölümünde belirtildiği üzere, "geçmişe”" doğru bu zihni yolculuğa çıkışın temel sebebi, uluslararası politik ekonomi alanında "günümüzde" meydana gelen hızlı dönüşümlerdir. Bunların "gelecekte" ortaya çıkarabilecekleri muhtemel dünya düzeni mimarileri hakkında eleştirel kuramın sunduğu perspektiften yararlanılarak fikir yürütülebilmesi için ise, yeni konjonktürle birlikte tarihselleşen analizlerin değişim dinamiklerini perdeleyerek yol açabilecekleri olumsuzluklardan sakınılması gerekmektedir.

Bu yüzden de kuramın temel teorik önermeleri ve analitik imkanlarının gözden geçirilmesi büyük önem taşımaktadır. Başarılabildiği takdirde, söz konusu kaygıyı paylaşan akademik çevreler, Ortadoğu'dan Doğu Avrupa'ya uzanan istikrarsız kuşaktan başlayarak geniş bir coğrafyadaki genişlemeleri çok ihtiyaç duyulanözgün perspektiflerden yorumlayabileceklerdir.

139 Cox, "Gramsci, Hegemony and InternationalRelations", s. 61.

140 Cox, "Social Forces, States and World Order", s.103, 105, 115.

141 Barbara Emadi-Coffin, Rethinking International Organization: Deregulation and Global Governance, Londra, Routledge, 2002, s. 28. 


\section{Kaynakça}

Adamson, WalterL., "Beyond 'Reform or Revolution': Notes on Political Education in Gramsci, Habermas and Arendt”, James Martin (der.), Antonio Gramsci, Critical Assessments of Leading Political Philosophers, Londra, Routledge, 2002, s. 289-318.

Althusser, Louis, For Marx, çev. Ben Brewster, Londra, Verso, 2005.

Anderson, Perry, “The Antinomies of Antonio Gramsci”, New Left Review, No100,1976, s. 5-78.

Aristotle, The Politics of Aristotle, Ernest Barker (çev.), Oxford, Clarendon Press, 1948.

Arrighi, Giovanni, “The Three Hegemonies of Historical Capitalism”, Stephen Gill (der.), Gramsci, Historical Materialism and International Relations, Cambridge, Cambridge University Press, 1993, s. 148-185.

Augelli, Enrico ve Craig N. Murphy, “Gramsci and International Relations: A General Perspective and Example from Recent US Policy Toward the Third World”, Stephen Gill (der.), Gramsci, Historical Materialismand International Relations, Cambridge, Cambridge University Press, 1993, s. 127-147.

Augelli, Enrico ve Craig N. Murphy: "Consciousness, Myth and Collective Action: Gramsci, Sorel and the Ethical State”, Stephen Gill ve James H. Mittelman (der.), Innovation and Transformation in International Studies, Cambridge, Cambridge University Press, 1997, s. 25-38.

Avni, Alexander ve Mira Sucharov, "Philosophical Realism", Routledge Encyclopedia of International Political Economy, R. J. Barry Jones (der.), Londra, Routledge, 2001, s. 1212-1213.

Barrett, Michele, Marx’tan Foucault'a İdeoloji, Ahmet Fehmi (çev.), İstanbul, Mavi Ada Yayıncılık, 2000.

Bieler, Andreas and Adam David Morton, "A Critical Theory Route to Hegemony, World Order and Historical Change:Neo-Gramscian PerspectivesinInternational Relations”, Capital \& Class, No 82, 2004, s. 85-114.

Bobbio, Norberto, “Gramsciand the Conception ofCivilSociety”, ChantalMouffe(der.), GramsciandMarxist Theory, Londra, Routledge, 1979, s. 21-47.

Bostanoğlu, Burcu, Türkiye-ABD İlişkilerinin Politikası, Ankara, İmge Kitabevi, 1999.

Bostanoğlu, Burcu, “Uluslararası İlişkilerde Metodoloji Tartışmaları ve Robert W. Cox”, Burcu Bostanoğlu ve Mehmet Akif Okur, Uluslararast Illişkilerde Eleştirel Kuram, Hegemonya, Medeniyetler ve Robert W. Cox, Ankara, Gazi Kitapevi, 2008, s. 15-66.

Bouillon, Markus E., "Gramsci, Political Economy, and the Decline of the Peace Process", Critique: Critical Middle Eastern Studies, Cilt13, No3,2004, s. 239-264.

Brilmayer, Lea, American Hegemony, Political Morality in a one-Superpower World, New Haven, Yale University Press, 1994.

Bunnin, Nicholas ve Jiyuan Yu, The Blackwell Dictionary of Western Philosophy, Oxford, Blackwell, 2004.

Cassels, Alan,Ideologyand International Relations in the Modern World,Londra, Routledge, 1996.

Cox, Robert W., “SocialForces, States and World Orders:Beyond International Relations Theory”, Millennium: Journal of International Studies, Cilt 10, No 2, 1981, s. 126-155.

Cox, Robert W.,Production Power and World Order: Social Forces in the Making of History, New York, Columbia University Press, 1987.

Cox, Robert W., "Middlepowermanship, Japan and Future World Order", International Journal, Cilt 44, No 4, 1989, s. 823-862.

Cox, Robert W., “Gramsci, Hegemony and International Relations: An Essay in Method”, Stephen Gill (der.), Gramsci, Historical Materialism and International Relations, Cambridge, Cambridge University Press, 1993, s. $49-68$.

Cox, Robert W. "Civil Society at the Turn of the Millenium: Prospects for an Alternative World Order”, Review of International Studies, Cilt 25, No 1, 1999, s. 3-28.

Cox, Robert W., “The International in Evolution”, Millennium: Journal of International Studies, Cilt 35, No 3 , 2007, s. 513-527. 
Cox, Robert W. ve Timothy J. Sinclair, Approaches to World Order, Cambridge, Cambridge University Press, 1996.

Cox, Robert W.ve Michael G. Schechter, The Political Economy of a Plural World: Critical Reflections on Power, Morals and Civilization, Londra, Routledge, 2002.

Dombroski, Robert S., Antonio Gramsci, Boston, Twayne Publishers, 1989.

Emadi-Coffin, Barbara, Rethinking International Organization: Deregulation and Global Governance, Londra, Routledge, 2002.

Entwistle, Harold, Antonio Gramsci: Conservative Schooling for Radical Politics, Londra, Routledge, 1979.

Femia, Joseph V., Gramsci's Political Thought: Hegemony, Consciousness and the Revolutionary Process, Oxford, Clarendon Press, 1981.

Ferguson, William Scott, Greek Imperialism, New York, Biblo \& Tannen Publishers, 1981,

Finocchiaro, Maurice A., Gramsci and the History of Dialectical Thought, New York, Cambridge University Press, 1988.

Fiori, Giuseppe Antonio Gramsci: Life of a Revolutionary, Tom Nairn (çev.), Verso Books, 1996.

Fontana, Benedetto, Hegemony and Power, On The Relation Between Gramsci and Machiavelli, Minneapolis, University of Minnesota Press, 1993.

Forgacs, David ve D. Sternbach (der.), An Antonio Gramsci Reader: Selected Writings, 1916-1935, New York, Schocken Books, 1989, s.190-200.

Gill, Stephen, "Gramsci and Global Politics: Towards a Post-Hegemonic Research Agenda”, Stephen Gill (der.), Gramsci, Historical Materialism and International Relations, Cambridge, Cambridge University Press, 1993, s. 1-20.

Gill, Stephen, "Epistemology, Ontology and the 'Italian School”, Stephen Gill (der.), Gramsci, Historical Materialism and International Relations, Cambridge, Cambridge University Press, 1993, s. 21-48.

Gill, Stephen ve David Law, "Global Hegemony and the Structural Power of Capital”, Stephen Gill (der.), Gramsci, Historical Materialism and International Relations, Cambridge, Cambridge University Press, 1993, s. 93-126.

Gramsci, Antonio, Selections From the Prison Notebooks of Antonio Gramsci, Quentin Hoare (der.), çev. G. Nowell Smith,New York, InternationalPublishers, 1978.

Hall, Stuart, Thatcherism and the Crisis of the Left: the Hard Road to Renewal, Londra, Verso Press, 1988.

Hobson, John M., The State and International Relations, Cambridge, Cambridge University Press, 2000.

Joseph, Jonathan, Hegemony, A Realist Analysis, Londra, Routledge, 2002.

Keyman, E. Fuat, “Eleştirel Düşünce: İletişim, Hegemonya, Kimlik/Fark”, Atilla Eralp (der.), Devlet, Sistem ve Kimlik, Uluslararası İlişkilerde Temel Yaklaşımlar, İstanbul, İletişim Yayınları, 2000, s. 227-260.

Laclau, Ernesto ve Chantal Mouffe, Hegemony and Socialist Strategy, Towards a Radical Democratic Politics, Londra, Verso, 1990.

Machiavelli, Niccolo, The Art of WarandThe Prince, Henry Nevilleve W.K. Marriott(çev.), Texas, El Paso Norte Press, 2005.

Martín-Barbero, Jesús, Communication, Culture and Hegemony, From the Media to Mediations, Elizabeth Fox ve Robert A. White (çev.), Londra, Sage Publications, 1993.

Merrington, John, “Theory and Practice in Gramsci's Marxism”, New Left Review (der.), Western Marxism, A Critical Reader, Londra, Verso, 1978, p. 140-175.

Mitchell, G.Duncan (der.),ANew Dictionaryofthe Social Sciences, NewJersey, Transaction Publishers, 2007.

Mittelman, James H., "World Order Studies and International Political Economy”, Alternatives, Cilt 9, No 3, 1983, s. 325-349. 
Mittelman, James H., "Rethinking Innovation in International Studies: Global Transformation at the Turn of the Millenium", Stephen Gill ve James H. Mittelman (der.), Innovation and Transformation in International Studies, Cambridge, Cambridge University Press, 1997, s. 248-263.

Morera, Esteve, Gramsci's Historicism: A Realist Interpretation, Londra, Routledge, 1990.

Mouffe, Chantal, "Hegemony and Ideology in Gramsci”, Chantal Mouffe (der.), Gramsci and Marxist Theory, Londra, Routledge, 1979, s. 168-204.

Okur,Mehmet Akif, “Millet-İmparatorluklarÇağınınEşiğinde: GenişleyenDünyada KüreselKapitalizmin Yeni MimarisineDoğru," Türkiye Günlüğ̈̈,No95,2008, s. 82-118.

Outhwaite, William, The Blackwell Dictionary of Modern Social Thought, Oxford, Blackwell, 2003.

Perlman, Shalom, "Hegemony and Arkhe in Greece: Fourth-Century B.C.Views", Richard Ned Lebow ve Barry S.Strauss (der.), Hegemonic Rivalry: From Thucydides to the Nuclear Age, Boulder, Westview Press, 1991, s. 269-286.

Pijl, Kees van der, “Transnational Class Formation and State Forms”, Stephen Gill ve James H. Mittelman (der.), Innovation and Transformation in International Studies, Cambridge, Cambridge University Press, 1997, s. 115-137.

Ransom, Paul, Antonio Gramsci, A New Introduction, Hempstead, Harvester Wheatsheaf, 1992.

Robinson, William I., Promoting Polyarchy: Globalization, USIntervention and Hegemony, Cambridge, Cambridge University Press, 1996.

Robinson, William I., "Globalization, fte World System and Democracy Promotion in US Foreign Policy", Theory and Society, No 25, 1996, s. 615-665.

Rupert, Mark, "Alienation, Capitalism and the Inter-State System: Towards a Marxian/Gramscian Critique", Stephen Gill (der.), Gramsci, Historical Materialismand International Relations, Cambridge, Cambridge University Press, 1993, s. 67-92.

Sassoon, Anne Showstack, Gramsci’s Politics, Minneapolis, University of Minnesota Press, 1987.

Sinclair, Timothy J., "Beyond International Relations Theory”, Robert W. Cox ve Timothy J. Sinclair, Approaches to WorldOrder, Cambridge, Cambridge University Press, 1996, s. 3-18.

Taylor, Ian, Stuck in Middle Gear: South Africa's Post-Apartheid Foreign Relations, Praeger, Greenwood, 2001. 